\section{Section 2}

17 水沢腎センター式透析用輸液セットの使用経験

$$
\text { 水沢腎センター }
$$

18

透析終了時, 残血量减少のための Critical-Point を求めて

埼玉県腎センター

19 残血量减少に関する $2 \sim 3$ の工夫

長野県厚生連篠, 井病院人工腎センター

20 各種ダイアライザーの回収方法の検討

府中腎クリニック

調布病院腎センター

21 我々の透析法 一除水, 残血減少等について一

南千住クリニック

22 コイル型と HFAK 型における残血减少の工夫

横浜市立大学人工腎センター

23 各種 Dialyser の返血方法と残血量

市立三笠総合病院人工腎センター

24 ヘパリン使用量の検討 一特汇残血量との関連一

京浜病院腎センター

25 最適 water treatment と終了時に打ける洗滌, 消毒法の検討

聖友会西新宿病院

聖友会四ッ谷クリニック $\begin{aligned} & \text { 司会川口良 } \text { 人 } \\ & \text { 沢西謙次 }\end{aligned}$

佐々木悦子, 松浦 玲子, 佐藤卜キ子

石川や兄子, 松本 百子, 岩㴊 国人

青野一㦀, 黒沼 一国, 福田 秀夫

小川 幸二, 栗山 学, 堀江 正宣

加藤 英夫, 伊賀 六一

重田三枝子, 湯原 時子, 竹内さよ江 西村 保子, 宮崎 澄江, 松木つた江

北沢 幸子, 塩沢勉, 新村 明

鈴木 克典, 太田 孝央, 土井 正勝

荒沢 陽子, 沼沢 良樹

谷山 繁彦, 井田 宏和, 中平 博之

倉島 健二, 福田 智之, 真鍋 昌世

小暮 史恵, 山内 和子, 川崎 久子

大石キヌ子, 桑原 啓泰, 杉崎 弘章

山上 省三, 月田 修次, 藤崎 悦郎

永井 知直, 沖本 錦吾, 菊地 晴男

上野 幸子, 梶原 哲郎, 蒲谷堯

北野まり子, 溝田シオリ, 小田桐ミチ 大石 邦子, 鈴木こず光，幸田登美子

小林 肇，小笠原雅幸

田中 金雄, 西方 憲雄, 土屋 寿 宮地 隆郎

一薬液, 熱湯, 蒸気一

雨宮 時夫, 佐藤 好文, 佐藤 卓

青沼 久, 吉田兄り子, 田代真知子

芝本隆, 浦田 義之, 小林力

高田 厳

26 透析準備時間の短縮 一特に HFK のホルマリン除去における迅速洗滌法の評価一

幸町診療所人工腎センター 服部 揖子, 中田 芳子, 岡田 啓子

渡辺敏子, 木村 恵子, 延原 和子

鈴木 正人, 野尻 昭晤, 船越 豊英

清水 憲, 国米 欣明

27 ダイアライザーの洗滌

.東京クリニック 松金 隆夫, 田中 政興, 岸均

星博, 品川茂 
28 ホロファイバー型ダイアライザーの洗滌と残存ホルマリン濃度について

公立忠岡病院人工透析室 中村 真砂, 前田 忠嘉, 高橋 陽子

斉藤 洋子, 長尾百合子, 丸田, 恵子

山上 征二, 吉本 忍

29 透析器中のエチレンオキサイドガスの残在量と洗滌効果について

大阪薬科大学 安田 正秀

木村腎クリニック 松本 真一

30 コイル・リーク・ディテクターの使用経験

守山クリニック 山田 志郎, 水野 求, 新谷 富男 長谷川辰寿, 土田 清春

31 各種コイルの圧テストの意義とェアーリンステクニックについて

県立厚木病院腎センター 北原 里子, 木村多美子, 安藤 陽子 久保寺 進, 田中 健一, 川村 博俊

32 リーク防止と残血減少の工夫

厚木クリニック和田了子, 常盤 タョ, 釜屋 正俊

三愛病院人工腎蔵室 中村 裕子, 菊池ひな子, 斉藤すみ 武蔵恵美子 
沢西 ただいまよりセクション 2 を始めさせていただ きます。

長期透析患者の貧血というのは, 非常に合併症として 避け難いものなんですが，やはり透析をやる患者さんの 貧血状態を何とか改善させていこうということになりま すと，透析回路及びダイアライザーの中にたまる血液を いかにして返していくか. またりークをできるだけ起こ さないよらにやっていかなければならない、で，このセ クションでございますが，残血及びリーク，そして間に ダイアライザーのウォッシュアウトといら問題が取り上 げられております。まず残血に関する問題，このところ を川口先生の司会の下に始めさせていただきまして, 後, ウォッシュアウト及びリークについて，私が司会させて いただきたいと思います。

川ロ では早速発表していただきます。

17 番, 水沢腎センターの佐々木さんに打願いします。

佐々木 水沢腎センターでは, 特別な透析用輸液セッ トを工夫し, 過去 1 年以上にわたり透析終了時の血液を 回収する際に使用しております。非常に具合がよろしい ので報告いたします。

一般に血液透析を終光て体外の血液を体内に戻す際に は, 残血量を少なくするために, 血液回路の動脈側から $100 \mathrm{ml}$ 汪どの輸液をしております，以前は普通の点滴 セットを $500 \mathrm{ml}$ の点滴びんにつなぎ, 点滴セットの先端 に付属している針やたこ管を捨て、ゴム管に血液回路の 動脈側を直接接続し，輸液をしておりました。しかしゴ ム管には患者の血液が付着するので，同じ点滴びんの中 に残っている液を次の患者に使用するためには，肝炎な どの接触感染を予防する意味から，新しい点滴セットを 接続しなければなりませんでした。例えば 1 人の透析患 者に $100 \mathrm{ml}$ 使うとしますと, $500 \mathrm{ml}$ の点滴びんは 5 人に 使克，5回も点滴セットを取り替光る必要があります. このよらにして何度も太い針を点滴びんのロにあるゴム 栓に刺していますと，3〜4 回目ごろから中の液が針穴 から漏れることがよくありました.

水沢腎センター式透析用輸液セットは, 一度セットし ますと刺し替えることなく，1 本の点滴びんの液を数人 の透析患者の血液を回収するために使用できる特徵があ ります（表 1). 構造は簡単で，ェアトラップやたこ管, 輸液針はなく，導入針に連絡管がつながり，その先にゴ ム管とビニール管が交互に連続してついて扣ります（図 1 ). 連結管部にはロールクランプが付いており, 容易に クランプができます，使い方も簡単です，体外の血液を。 静脈内に回収するときには，最終のゴム管（4n）を血 液回路の動脈側端に接続し，必要な量を輸液します。1 人目の患者への輸液が終わったらクランプし, 手前のビ
I . 回収作業の能率化
a. 1 本のセットで数人の血液を回収
b. セットの刺し変え不要
c. 水の漏洩なし
II. 経費の節約
a. 構造が簡単
III. その他
b. 安価にできる
a 、肝炎の危険なし
c . 省資源
b. 実用新案申請中
c. J M S 製

表 1 水沢腎センター式透析用輸液セットの特徵

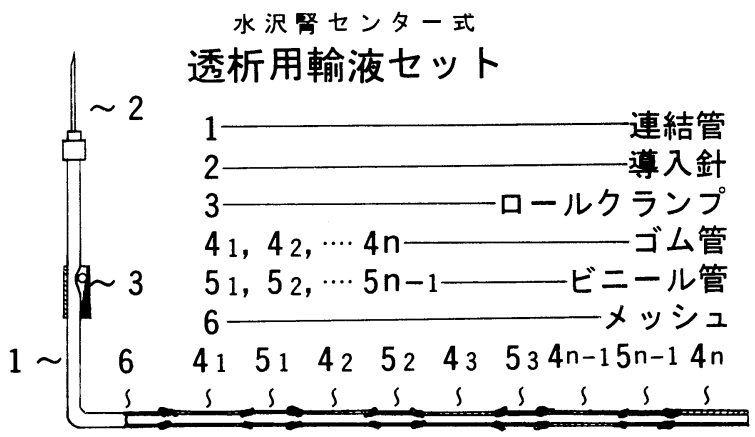

図 I

ニール管 $(5 \mathrm{n}-1)$ の部分を次のゴム管 $(4 \mathrm{n}-1)$ よりはずします。透析用輸液セットを付けたまま点滴び んを移し，ゴム管 $(4 \mathrm{n}-1)$ を 2 人目の患者の輸液に 使用します，以下このようにして，ゴム管の数だけ刺し 替えずに，異った透析患者の輸液に使用できます．現在 使っている透析用輸液セットにはゴム管が 5 個付いてお ります.

この透析用輸液セットを実際に使ってみますと, いろ いろ便利な点があります。一々刺し替える煩わしさがな くなり，連続して 5 人の血液を回収できるため，能率的 な作業がでさます。つまり慌ただしい透析終了時に従来 は数個の輸液セットの袋を破り, 針やたこ管を捨て, セッ トするといらむだをしていたことになりますまなた何度 も針を刺していたときによく見られた点滴びんのゴム栓 よりの不快な水漏れが全く見られなくなり，清潔な回収 作業が行えるようになりました。

構造が簡単なため, 安価にでき, 従来の点滴セット 2 本分弱の価格で, 従来の点滴セット 5 本分の役割りをし, 割安です. 以前は 1 人 1 人の回収の都度に点滴セットを 1 組ずつ捨てていましたが, この透析用輸液セットでは, 先に付いているゴム管，長さ約 $6 \mathrm{~cm}$ を 1 個ずつ捨てて いき，最後には連絡管，長さ約 $1.2 \mathrm{~m}$ 点滴びんごと捨 てるわけです。したがって捨てる輸液セットのごみの量 は従来の約 $1 / 5$ には少なくなり，省資源的であります。 
そのほか, 回收作業に血液が透析用輸液セット側に逆流 することはありませんので，以前の 1 回ごとの点滴セッ トを捨てていた方法と比べ，特に肝炎などに感染する危 険が増すとは考えられません。是非皆様にも拉試しいた だき，御批判をいただければ幸いと存じます。

川口 次は 18 席の埼玉県腎センターの青野さんにお 願いします。

青野 慢性腎不全患者の貧血の原因は，骨䯣に打ける 赤血球産生の低下と赤血球破壊の高進によるものが主だ と考光られている．また血液透析に関しては血液口スも 貧血に対する大きなファクターであり，1つとして，回 路内残留血液量 $(\mathrm{RBV})$ の問題があり，この徹底回収が 必要であると考えられている.

ある日の血液透析前後の $\mathrm{Ht}$ を比較すると，泀とんど $\mathrm{Ht}$ の増加が認められるため, 一層血液回収の必要があ るわけである。今回我々は, 血液ポンプ回転数と血液回 路洗浄液量变变化, 比較させて, 最も残血の少ないクリ ティカルポイントを求めることを目的に以下の検討を 行った.

対象は，埼玉県腎センターで慢性血液透析療法施行中 の患者である. 透析器は日機装社製の CD-11, ダイアラ イザーは EX-03 を使用した. 従来の血球を用いた方法, 赤血球, 白血球, $\mathrm{Ht}$ などで行うと, 溶血による誤差が生 じやすいために，我々は生体内に多量にあるアルブミン を用いると容易でかつ正確に測定可能であると考㝋た。 そこで，Aを透析終了值前の患者の生体内アルブミンボ リューム，Bをダイアライザー及び血液回路内の残血量 を生理食塩水を用いて完全に洗浄したボリューム，Cを B中に打けるアルブミンボリュームとし，以下の式によ り $\mathrm{RBV}$ を求めた. $\mathrm{RBV}=\mathrm{B} / \mathrm{A} \times \mathrm{C}$, ダイアライザー及 デ血液回路内の洗浄は, 体外血液を設定生理食塩水で還 血した後, 更に約 $200 \mathrm{ml}$ の生理食塩水を用いて洗浄し, そのボリュームを使用した. アルブミン測定法はマンチ 二ーの方法に従い, SRID 法を用いた. そして血液ポンプ 回転数は $5,10,15,20$ 回転, 生理食塩水は 50,100 , $150,200 \mathrm{ml}$ と, それぞれ 4 段階に分けて行った。

横軸に生理食塩水量を, 縦軸に残血量をとり, 生理食 塩水を多量に使用すると残血が少なくなる傾向にある が，血液透析の目的の 1 つである除水のみをなさなく なってしまう．特徵的なことは，生理食塩水量の $100 \mathrm{ml}$ と $150 \mathrm{ml}$ の間にギャップが認められる傾向にあること である.

横軸に血液ポンプ回転数, 䅠軸に残血量をとり, 比べ てみると，その中で $150 \mathrm{ml}, 20$ 回転と $200 \mathrm{ml}$ の各回転数 でよい結果が得られた。 そこで, 生理食塩水を抑兄て, 残血の少ない $150 \mathrm{ml}, 20$ 回転をクリティカルポイントと
した.

従来, 当センターでは, 生理食塩水 $40 \mathrm{ml}, 10$ 回転で還 血していたが, 今回の結果から, $150 \mathrm{ml}, 20$ 回転を採用す ることにより, 残血量は月 9 回の透析で $59 \mathrm{ml}$ から $12 \mathrm{ml}$ まで, 約 $47 \mathrm{ml}$ 回收することが可能になるわけである. も らろん RBV を規定する因子としては, 今回検討した回 転数, 洗浄液量によってのみ決まるものでなく, 血液粘 度, $\mathrm{Ht}$ ，凝固時間等，個々の生体側因子も考慮に入れな ければならないであろう。今後, こうした点について更 に検討していく予定である.

川口 討論は, 24 番の演題が終わった時点で一括して 残血について討論したいと思いますので, このまま演題 を続けさせていただきます。

次は, 19 番の長野県厚生連篠ノ井病院の人工腎セン ターの重田さん,ぞうぞ.

重田 当透析センターでは, 現在 52 名の透析を行って います．長期透析患者の貧血原因の 1 つとて考兄られ る残血量を減少させることができましたので報告いたし ます。

対象機種は $\mathrm{CDAK}$ モデル 4 が 8 名, RP モデル 5 が 10 名，ギャンブローオプテマ型 6 名であります。期間は 5 月から 11 月, 方法は, 開始時へパリン量はキール型 2000 単位, CDAK 3000 , 透析中は 1300 から 1700 単位使 用し，透析中の凝固時間をザーリホニ才法で開始，13 か ら 20 分に調整, 回収時の血流は毎分 50 から $70 \mathrm{~m} l$ であ ります。残血量の測定法は, ダイアライザーを解体して 生食で洗浄し, その中の総赤血球数より患者の血液量を 換算しました。

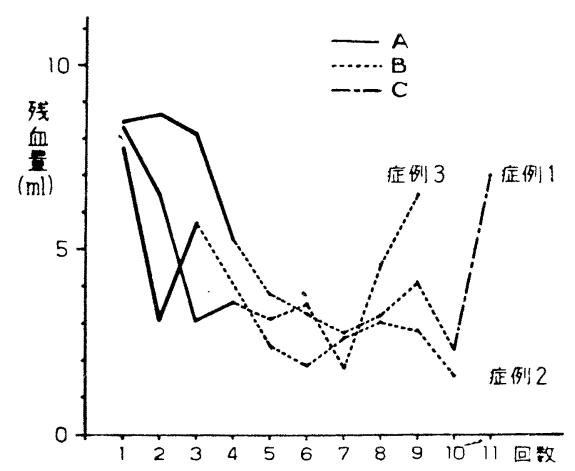

\begin{tabular}{|c|c|c|c|}
\hline 回収方法 & A & B & $C$ \\
\hline 洗㜔! & $100 \mathrm{ml}$ & $150 \mathrm{ml}$ & $100 \mathrm{ml}$ \\
\hline 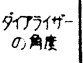 & $\begin{array}{l}\text { 啝例を上に } \\
\text { 重直 }\end{array}$ & $\begin{array}{c}45^{\circ} \sim 50^{\circ} \\
\text { 钼斜 }\end{array}$ & $\begin{array}{c}45^{\circ}-50^{\circ} \\
\text { 倾面斜 }\end{array}$ \\
\hline
\end{tabular}

図 $1 \mathrm{RP}$ 症例及び回收方法別残血量

図 1 は RP の症例及び回収方法別残血量を示したも 
ので, 方法 Aは，血液を静脈チャンバーまで戻し，生食 $100 \mathrm{~m} l$ 後空気で回収, B は, 生食を 150 に増やし, それ がダイアライアライザー全体に行き渡るよう, 動脈側を 50 度前後に傾け注入後, 更に動脈側を上にしてまんべん なく振りながら回収，Cは，ダイアライザーを傾け，生 食をBより 50 減らしてみました. その結果，Aは奥の層 に，Bは全体に血液が多いため，やはり 150 の洗浄液を ダイアライザーにまんべんなく行き渡るよう振りながら 回収するBの方法が一番良いとわかりました。

図 2 は CDAK の症例及び回收方法別残血量を示した もので, Aは開始時, 陰圧 150, 終了時は生食 150 から 200 流し続け，きれいになったところで止めました。この方 法は鎖状に血液が残り，開始時に拈ける動脈側の空気が 原因と考光，Bでは，準備中，陰圧ゼロにし，更にダイ アライザー, 動脈の空気を除去して, 生食 150 使用後, 空気で回収, Cは開始時, 空気を除去し, 生食 150 から 200 で流し続け，きれいになったところで止める方法で す.

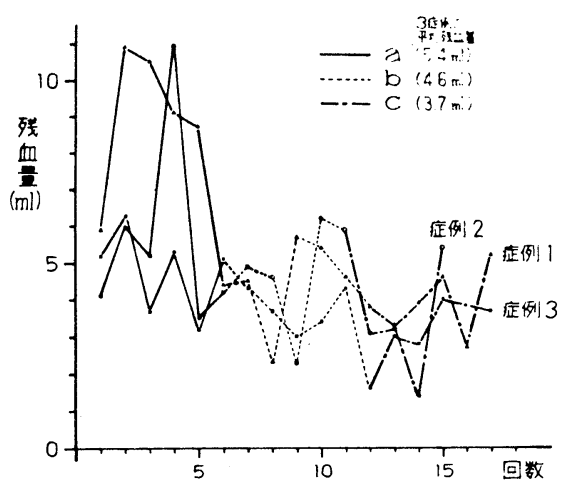

\begin{tabular}{|c|c|c|c|c|}
\hline \multicolumn{2}{|c|}{ 施 } & a & $b$ & $C$ \\
\hline \multirow{2}{*}{$\begin{array}{l}\text { 開 } \\
\text { 始 } \\
\text { 時 }\end{array}$} & 陰压 & $150 \mathrm{~mm} H \mathrm{~g}$ & 0 & 0 \\
\hline & 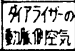 & 除去せず & 除去 & 除去 \\
\hline \multirow{2}{*}{ 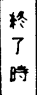 } & 陰压 & $150 \mathrm{mmHg}$ & $150 \mathrm{mmHg}$ & 0 \\
\hline & 洗浄液 & $\begin{array}{l}150 \mathrm{ml} \\
\sim 200 \mathrm{ml}\end{array}$ & $\begin{array}{l}150 \mathrm{ml} \text { 徙 } \\
\text { 空気使用 }\end{array}$ & $\begin{array}{l}150 \mathrm{ml} \\
\sim 200 \mathrm{ml} \\
\end{array}$ \\
\hline
\end{tabular}

図 2 CDAK症例別及び回収方法别残血量

以上の結果, 開始時より動脈側の空気を除去し, 回収 時はダイアライザーを軽くたたいて振りながら水平まで 傾け, 洗浄後は安全性の面からも流し続け回収すること が一番良いとわかりました.

次に機種別の平均残血量を従来の方法と改良後を比較 しますと, CDAK は $44 \%, \mathrm{RP}$ は $50 \%$, このように残血 を減量できました. 機種別では, RP とギャンブローを一 番良い方法で比較すると, 有意差は見られませんでした.

残血量は血液の凝固能やその他の要素にも左右される と考光られますが，適切なへパリン量と，例えわずかな
血液でも, 患者の身となり, 細かな神経をつかって操作 することが大切であります。

川口＼cjkstart次は府中腎クリニックの鈴木さんにお願いいた します。

鈴木 近年, 各種透析器, ダイアライザーの改良, 透 析技術の進歩により，長期透析患者が増加してまいりま したが, 患者にとって負血の問題は大きく, 我々も蛋 白同化ホルモンの投与を初め, 各種薬剤の投与, 必須了 ミノ酸投与などを行い，でき得る限り貧血を改善してお りますが，リーク，残血による失う量は無視できないと 考え, 今回は各種ダイアライザー別に残血量を測定し, 回収方法について検討を加方, 多少の知見を得たので報 告します。

使用ダイアライザーはウルトラフローII, スタンダー ド及びポイント 1.5 , メラC $-35,40,50$, ギャンブロー ルンディアオプティマ, ローヌプーラン 5 型, パラフ ロー, 旭 $\mathrm{HF} \neq ー ル, \mathrm{~K}-12$, ドライタイプ, ダス ב SP-1052, シングルパスを残血量測定ダイアライザー としました（表1）.

\begin{tabular}{|c|c|}
\hline 型 & ダイアライザー名 \\
\hline $\begin{array}{l}コ \\
\text { ル } \\
\text { フ } \\
\text { 型 }\end{array}$ & $\begin{array}{l}\text { Ultra - Flow II standard } \\
\text { point } 1.5 \\
\text { Mera - } \mathrm{C}-35 \\
\mathrm{C}-40 \\
\mathrm{C}-50\end{array}$ \\
\hline $\begin{array}{c}\text { キ } \\
1 \\
\text { ル } \\
\text { 型 }\end{array}$ & $\begin{array}{l}\text { Gambro Lundia optima } \\
\mathrm{R} \mathrm{P}-5 \\
\text { Para-flo } \\
\text { Dasco SP-1052 single pass } \\
\text { Asahi-H F K, K-12(Dry) }\end{array}$ \\
\hline
\end{tabular}

表 | 使用ダイアライザー

\begin{tabular}{|c|c|}
\hline 方法 & 手 \\
\hline 法 & $\begin{array}{c}1 \text { 次回収：回収薬液 } 50 \text { 又は } 100 \mathrm{ml} \text { でダイアライザー } \\
\text { 内を洗浄回収 } \\
2 \text { 次回収：Airでダイアライザー内を洗浄回収 } \\
3 \text { 次回収：回収薬液 } 50,100 \text { 又は } 150 \mathrm{ml} ゙ \text { 再度洗浄 } \\
\text { 回収 }\end{array}$ \\
\hline $\begin{array}{l}\text { B } \\
\text { 法 }\end{array}$ & $\begin{array}{c}1 \text { 次回収：Air でダイアライザー内の血液を返血回収 } \\
2 \text { 次回収：回収薬液 } 100,150,200,250 \mathrm{ml} \text { でダイ } \\
\text { アライザー内を洗浄回収 }\end{array}$ \\
\hline
\end{tabular}

回収薬液： $5 \%$ ブドウ液, 生食水, 必須アミノ酸含液

表 2 回収方法 
回収方法は，まずA法とB法に分け，A法は表 2 で示 しましたように薬液で回収, 次にェアで回収, 再び薬液 で回収といらように 3 段階に分け回収しました. B法は， まずェアで回収した後, 薬液で回収し，2段階に分け回 収しました。そとて終了した回路，ダイアライザーを生 食水 $500 \mathrm{~m} l$ で洗い, その液中の赤血球数を算出し, 残血 量としました。 なお，回収テクニックはダイアライザー を回転させながら，また数回陽圧を掛けながら回収を行 い, 一応一定の方法で行いました。

図 1 では, 回路, ダイアライザーを洗浄した生食水中 の赤血球数を縦軸に， A 法と B 法の違いを横軸にとりま した。な报, 回收薬液量の違いにより，A法を更に $\mathrm{A}-1$, $\mathrm{A}-2, \mathrm{~A}-3, \mathrm{~A}--4, \mathrm{~B}$ ⿸ $\mathrm{B}-1, \mathrm{~B}-2, \mathrm{~B}-3$, B-4に分けました。図1で扔わかりいただけると思い ますが, 回収薬液量を増加していくと残血量は減少し, $200 \mathrm{~m} l$ 及び $250 \mathrm{~m} l$ の $\mathrm{A}-3, \mathrm{~A}-4, \mathrm{~B}-3, \mathrm{~B}-4$ で は, コンスタントに赤血球数 $5,000 \mathrm{~mm}^{3}$ 以下を示し, 液量 だけから判断すると, $250 \mathrm{~m} l$ が最適量であります。また

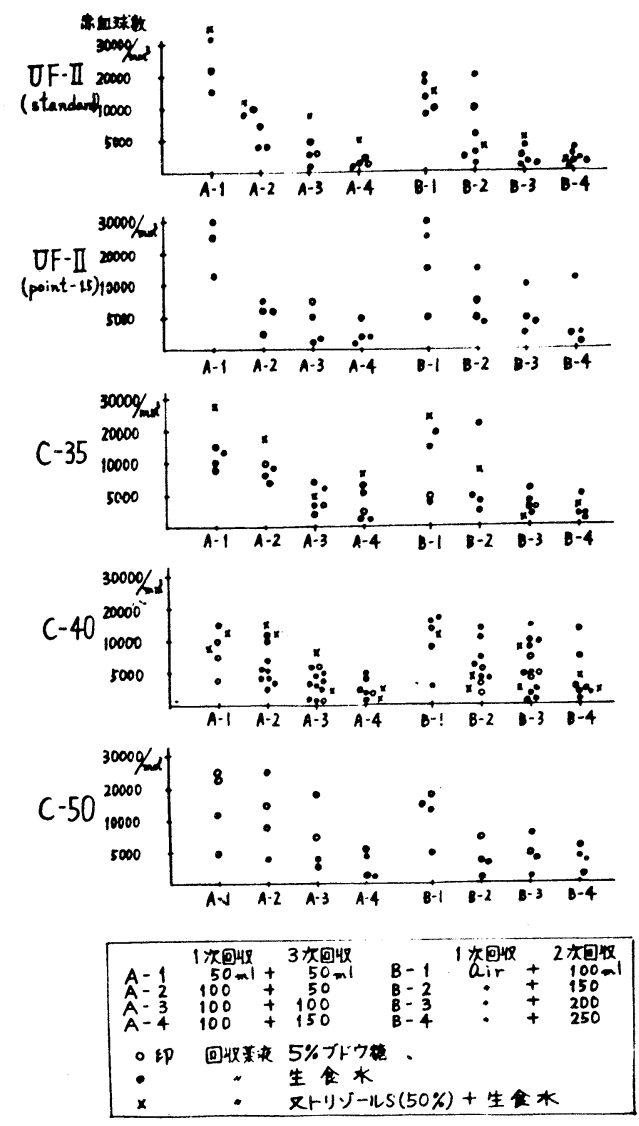

四、残血量結果 (コルフ型)
$100 \mathrm{~m} l$ の回収液量は $\mathrm{A}-1, \mathrm{~B}-1$ に示してあります が, 残血量が多く, 量的には不足と考光られむした。

次に薬液については, 生食水, $5 \%$ \%ブドウ糖共に大差 はありませんが，必須了ミノ酸を付加した生食水では， 粘稠のためか, 付加しない薬液よりも残血が多いことが わかりました，A法とB法の違いは，B法で残血が多い 症例はほとんどがダイアライザー内でクロッティングし ている場合で, 回収前にへパリン 500 単位, $0.5 \mathrm{~m} l$ を注 入し，クロッティングを防止して回収すれば，A法より B法の方が残血が少ないようであります。

キール型の残血量測定結果でもコルフ型と同じ結果を 得られましたが(図 2)，ギャンブローとバラフローは残 血が少なく,これらのダイアライザーは $100 \mathrm{~m} l$ の回収後 で十分と考学られました．HF キールドはドライタイプ のためか，残血が一般に多く，更に回收方法を検討しな ければならないと考光交した。一般的にキール型の方が コルフ型より残血が少ない傾向を認めました.

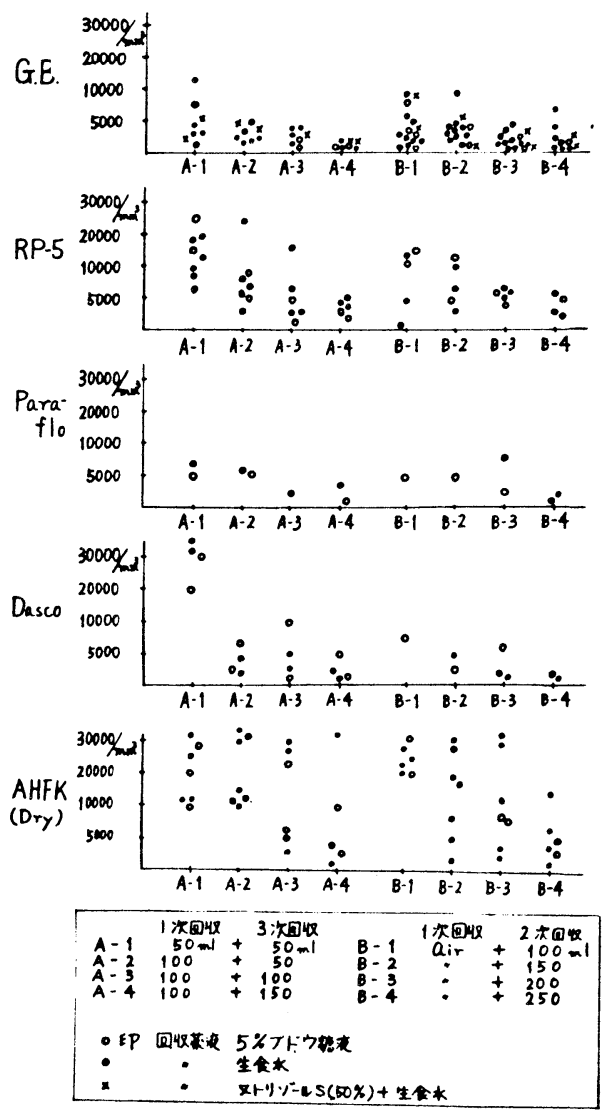

国 2 残血量結果 (キール型) 
結論として, 1. 回収方法はB 法の方が $\mathrm{A}$ 法より残血が 少ない傾向を認めるが， B 法はダイアライザー内のク ロッティングなどを認めることがあり，技術的にはA法 の方が安定している．2．として, 回收液量は 150 から $250 \mathrm{ml}$ が安定し, 患者の状態に合わせて回収液量を決定 すれば良い. 3 . 回收液は生食水, $5 \%$ ブドウ糖液共に大 差はないが，必須アミノ酸を付加した生食水はA法で残
血が多いことがわかりました。

川口 次は 21 番, 南千住クリニックの山上省三さんに お願いします。

山上 長期血液透析における正確な除水々残血減少の 重要性は周知のごとくでありますが, 実際にはディスイ クを起こさずに正確な除水量を得ることは困難でありま す. そこで，我々の行っている除水法と残血減少法につ
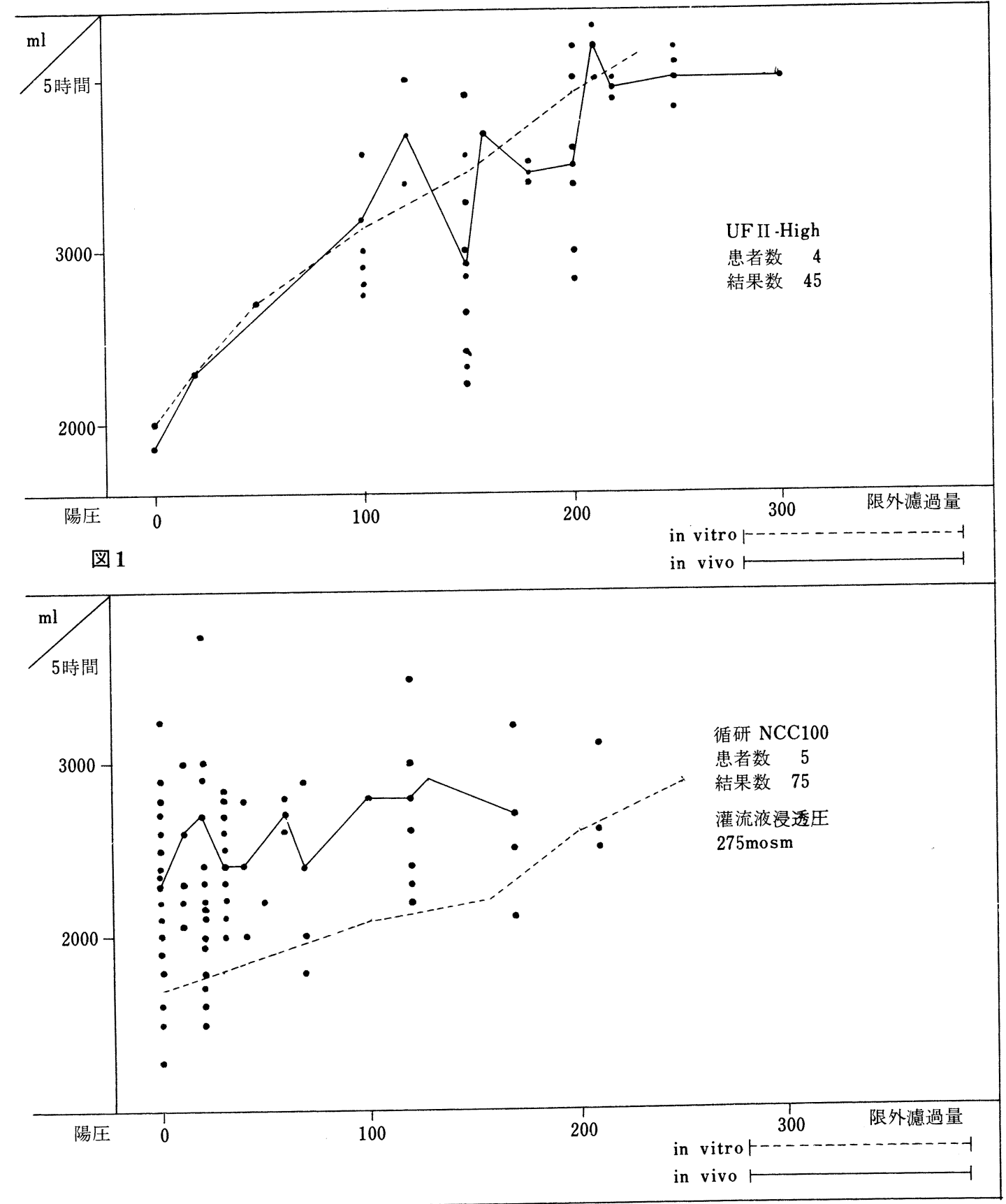

図 2 
いて報告します。

まず，正確な除水を得るために，我々の使用している 6 種類のダイアライザーにつき, 限外濾過圧との関係を 調べてみました。

図 1 の縦の軸は 5 時間透析に打ける除水量で，横の軸 は限外濾過圧, 点線はインビトロです。実線は我々の出 したインビボの平均です。また灌流液浸透圧は 2750 s $/ 1$
です. ウルトラフローII八イ，患者数 4 人，ダイアライ ザー使用数 45 , このダイアライザーについては除水量の 幅に開さがあり，限外濾過圧と除水に一定の関係は見出 しにくいが，多量な除水には可能であります．次に図 2 は循研 NC-100 患者数 5 人, ダイアライザー使用数 75 , このダイアライザーについては除水量の幅に開きがあ り，限外濾過圧と除水の関係にも一定の幅は見出せな

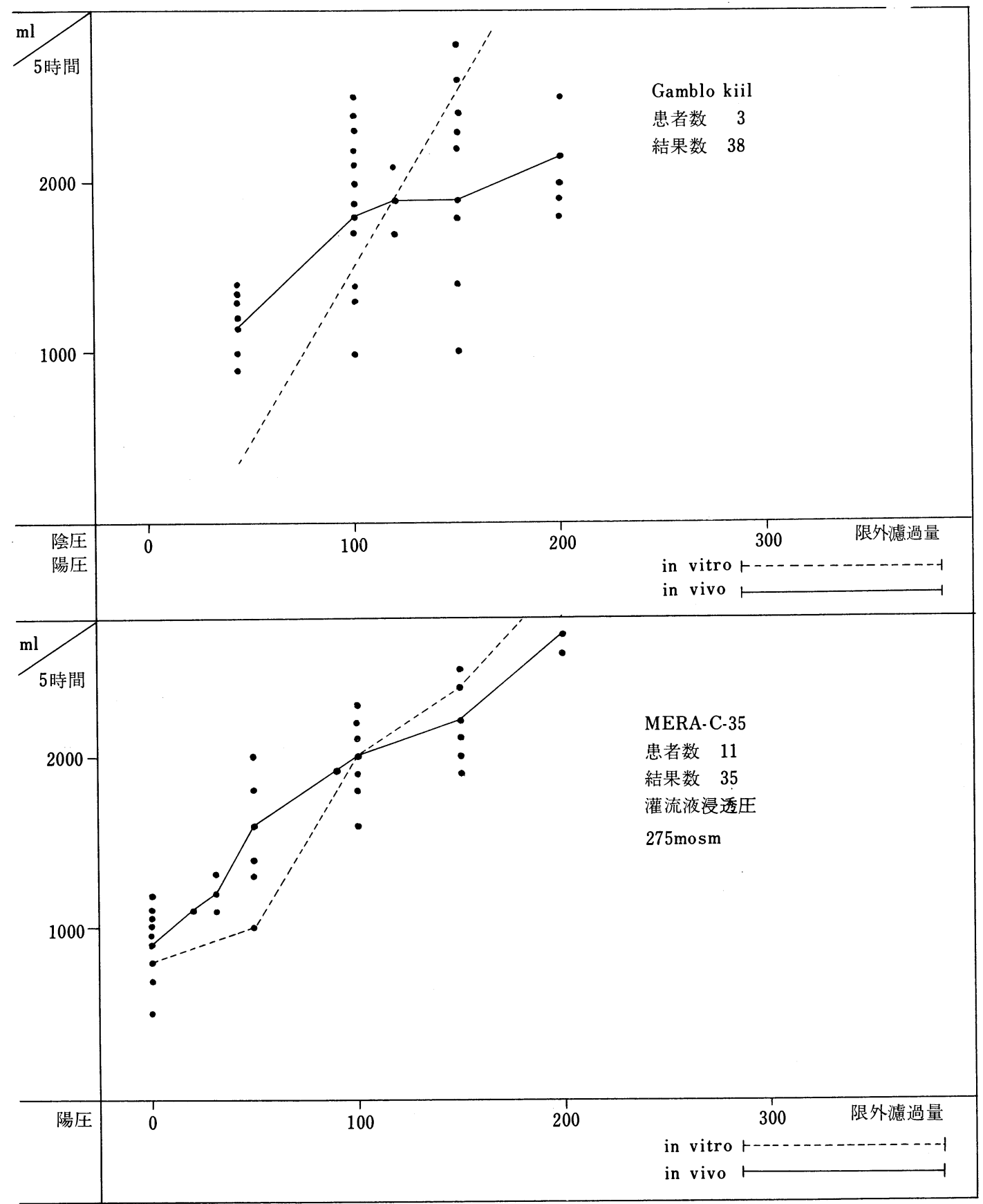


かった。

図 3 はギャンブローキール, 患者数 3 , ダイアライザー 使用数 38 , このダイアライザーについては $100 \mathrm{mmHg}$ と $150 \mathrm{mmHg}$ は除水量に幅がある. $50 \mathrm{mmHg}$ と 200 $\mathrm{mmHg}$ については除水量の幅がなく，また明らかに 50 $\mathrm{mmHg}$ と $200 \mathrm{mmHg}$ の除水量に差が見られ, 限外濾過 での使用は可能であります。

図 4 はメラC-35, 患者数 11 , ダイアライザー使用数 35, このダイアライザーについては除水量の幅も余りな く，限外濾過圧と除水との一定の関係が見られた.

次にダスコ,ダイアレックス SP-1052, 患者数 2 , ダ イアライザー使用数 45 , このダイアライザーについても 除水量に幅が余りなく，限外濾過圧と除水との関係が一 定の傾向が見られた．次に旭 HFK，K-12，患者数 3 ， ダイアライザー使用数 59 , このダイアライザーについて は除水量の幅が広く見られるが，限外滤過圧と除水の一 定の関係が見られた.

これらのインビボのデータを出した結果, 多量な除水 の夕使用できるもの，少量の除水のみ使用できるもの， また除水量の幅がなく，限外濾過圧と除水の一定した関 係を持つもの，このようにダイアライザーによってもい ろいろな特質があり，またそれぞれの特質を利用し，患 者さんの使用するダイアライザーを選択しています。 た限外濾過圧の設定についてですが，患者さんの体重増 加分十食事 $450 \mathrm{~g}+$ プライミングボリューム $200 \mathrm{ml}+$ 回 収生食水 $150 \mathrm{ml}$ を総合増加分とし，インビボのデータに のっとり限外濾過圧を設定しています。

次に残血减少について報告します。我々はサンドイッ チ法という回収法を使用しています。その内容は, まず $30 \mathrm{ml}$ から $50 \mathrm{ml}$ の生食を流し, その後空気を入れ, ダイ アライザー内の血液がほとんど回収された後, $100 \mathrm{ml} の$ 生食を流します，この方法をサンドイッチ法と呼んでい ます。この回収法を利用した結果，表1にあると拈り， まず 3 種類のコイルを使用し，患者数はコイルごとに各 1 名, 残血量は各 5 例の平均をとったものです. メラC $-35, \mathrm{Ht} 26$, サンドイッチ法では残血量, $1.1 \mathrm{ml}$, サンド

\begin{tabular}{|c|c|c|c|}
\hline $\begin{array}{r}\text { ダイヤライザー } \\
\text { 名 }\end{array}$ & $\mathrm{Ht}$ & $\begin{array}{r}\text { サンドイッチ法 } \\
\text { 各5 例 }\end{array}$ & $\begin{array}{c}\text { サンドイッチ法 } \\
\text { 各5 例以外の方法 }\end{array}$ \\
\hline MERA.C-35 & 26 & $1.1 \mathrm{cc}$ & $1.5 \mathrm{cc}$ \\
\hline $\begin{array}{c}\text { 循研 NCC } \\
\text { トラベノール } \\
\text { UF II Hi }\end{array}$ & 20 & $1.09 \mathrm{cc}$ & $1.54 \mathrm{cc}$ \\
\hline
\end{tabular}

表 I 残 血 量
イッチ法以外では残血量 $1.5 \mathrm{ml}$, 循研 NCC-100 は $\mathrm{Ht} 31$, サンドイッチ法では残血量 $2.4 \mathrm{ml}$, サンドイッチ 法以外では残血量 $3.8 \mathrm{ml}$, トラベノール, ウルトラフロー II ハイ, Ht20, サンドイッチ法では残血量 $1.09 \mathrm{ml}$, サン ドイッチ法以外では残血量 $1.54 \mathrm{ml}$, このように, サンド イッチ法は残血減少についてかなり有効と思われます。

我々は，今後もサンドイッチ法を使用したいと思いま す.

以上，我々の行っている除水と残血減少につき報告し ました。

川口＼cjkstart次は 22 席の横浜市立大学人工腎センターの溝 田さんにお願いします。

溝田 長期透析療法を行ら慢性腎不全患者にとって， 貧血は重要な障害の 1 つであります。そこで私どもは， 1. 残血量の減少, 2. 安全性の向上, 3 . リンス液の減少, 4. 省力化という4つを目的として,よりよい方法で血液 回収が行えるよう，この研究を実施しました。

一般に一般状態が安定し，EX-21，23，25，K-12 を使 用している患者を対象としました（表1）.

\begin{tabular}{|c|c|c|c|c|c|}
\hline $\begin{array}{l}\text { 多ア } \\
\text { 方法 }\end{array}$ & $\mathrm{EX}_{-21}^{-01}$ & $\mathrm{EX}_{-23}^{-03}$ & $\mathrm{EX}-25$ & $\mathrm{~K}-12$ & 所要時間 \\
\hline A & $\begin{array}{c}\text { 平均 } \mathrm{ml} \\
1.7\end{array}$ & $12.5^{\mathrm{ml}}$ & $\mathrm{ml}$ & $\mathrm{ml}$ & $\begin{array}{c}\text { 平均 分 } \\
3\end{array}$ \\
\hline B & 1.9 & 7.2 & & & 8 \\
\hline $\mathrm{C}$ & 1.7 & 3.0 & & & 15 \\
\hline D & & 2.9 & 2.3 & 3.2 & 6 \\
\hline $\mathrm{E}$ & & 1.3 & & & 8 \\
\hline 平均残血量 & 1.7 & .5 .3 & 2.3 & 3.2 & \\
\hline
\end{tabular}

表 ।

方法 $\mathrm{A}$, 生食水 $250 \mathrm{ml}$ の及, 方法 $\mathrm{B}$, 生食水 $100 \mathrm{ml}$ 注 入後, 空気を 2 分間送入し, コイル内を $100 \mathrm{mmHg}$ 加圧 し, コイルを倒立させ, 再度, 生食水 $150 \mathrm{ml}$ 注入します。 方法 $\mathrm{C}$ ，最初に空気を 6 分間送入し、コイル内を 100 $\mathrm{mmHg}$ 加圧し, 生食水 $200 \mathrm{ml}$ 注入後, コイルを倒立さ 世, 再度, 生食水 $50 \mathrm{ml}$ 注入します. 方法 D, 生食水 100 $\mathrm{ml}$ 注入後,コイルを倒立させ, カプロファンの巻き方に沿 ってコイルを頻回に回転させ, 後は空気で押し出します。 方法 $\mathrm{E}$, 生食水 $150 \mathrm{ml}$ 注入後, 空気を 2 分間送入し, コ イル内を $100 \mathrm{mmHg}$ 加圧し, コイルを例立させ, 再度, 生食水 $150 \mathrm{ml}$ 注入します. $\mathrm{K}-12$ については, 生食水 100 $\mathrm{ml}$ 注入後, $\mathrm{V}$ 側のドリップチャンバーの下をクランプ し, 空気抜きを行い, 血液がドリップチャンバー内にた まりましたら患者側に回収します。この操作を $3 \sim 4$ 
回繰り返し，その間にパルス操作も同時に行います。 た限外濾過圧は可能な限り一定にし, 同一方法に対し 15 〜20 回試みました.

残血量の算出方法, コイル内の血液を患者側へ回収後, カプロファン膜を取り出し, その膜に付着している血液 を $250 \mathrm{ml}$ の生食水で洗浄し，その一部を末梢血と同様の 方法で赤血球数を算定し, 残血量を求めました. 式は表 2 のごとくです.

測定方法の正確度については, 生食水 $250 \mathrm{ml}$ 中に 1 , $2,3,4,5,7.5,10,20 \mathrm{ml}$ の既知の赤血球数の血 液を希釈し，これを上記の方法で算出し，正確度を確認 しましたので沶示しします.な招, 相関係数ですが, $\mathrm{r}=$ $0.9712, \mathrm{Y}=0.7481 \mathrm{X}+0.05786$ ，な拈， $\mathrm{n}$ 数は 24 です.

結果は図 1 のごとくであります.

算 出 式

$$
\text { 残血量 }=\frac{\text { 採取したリンス液量 } \times \text { その赤血球数 } / \mathrm{mm}^{3}}{\text { 本人の赤血球数 } / \mathrm{mm}^{3}}
$$

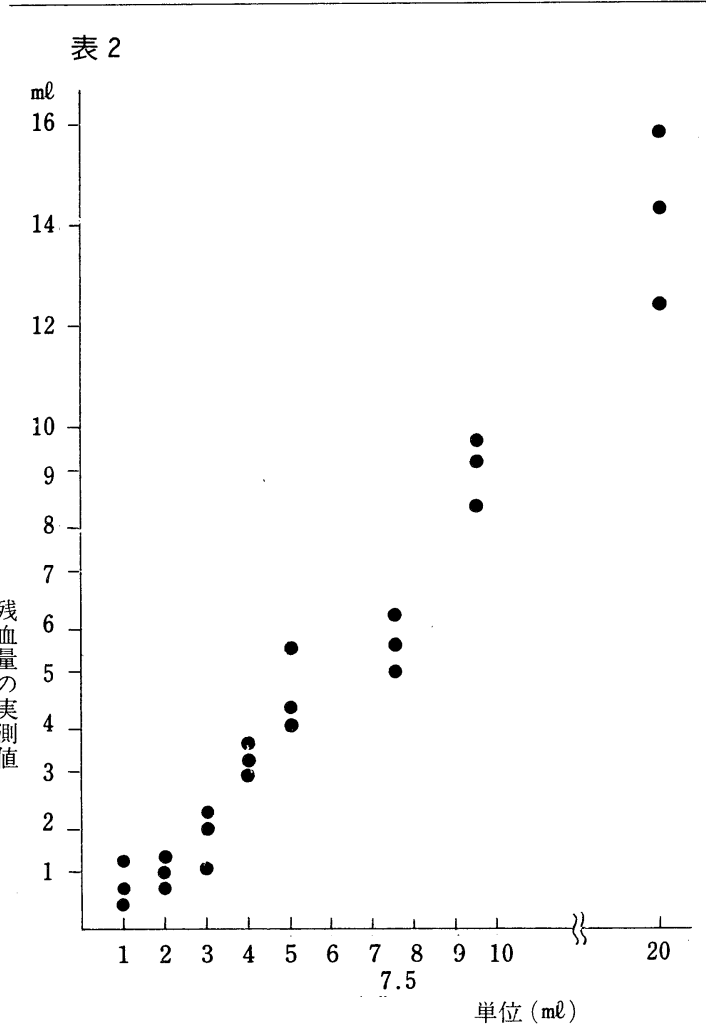

図１赤血球数による残血量測定の正確度
以上の結果, 方法 $\mathrm{D}$ の残血量は方法 $\mathrm{E}$ より平均 $1.6 \mathrm{ml}$ ほど多いですが，その他の安全性，リンス液の減少， 省力化という点ではすべて勝っていますので, 当セン ターでは方法Dを採用しています。しかし，ほかの方法 より安全性が高いといっても, 空気栓塞や凝結の可能性 が皆無ということではありませんので，それらを予防す るために, 術者各々が細心の注意を払い血液回収を行う 必要があると思います。

川口 次は 23 番の市立三笠総合病院人工腎センター の小林さん.

小林 慢性血液透析患者の合併症の 1 つに筫血があ り, 治療方法として各種の薬物療法が効果を上げている. しかし，透析ごとに失われていくダイアライザー内残血 量に対しても一定の基準を設け，残血量を極力抑えるよ らにしなければ，よい貧血対策とは言い難い，以上の観 点より, 我々は各種ダイアライザーの返血方法と残血量 及び測定方法に検討を加えた。

対象, 当人工腎センターにて血液透析を施行している 症例に, 表 1 に示した 11 種類のダイアライザーを使用し た。

\begin{tabular}{|c|c|c|c|c|}
\hline Type & Dialyser & Rins 量 $(m \ell)$ & 返 血 方 法 & 所要時間 \\
\hline \multirow{3}{*}{ Coil } & $\mathrm{EX}-20$ & 100 & \multirow{3}{*}{$\begin{array}{l}2 \text { 回に分けて rins し血液の } \\
\text { 流れに沿って coil を回転 } \\
\text { させる目的で介助者をつけ } \\
\text { る。 }\end{array}$} & \multirow{3}{*}{$\begin{array}{l}10.7 \\
(\min )\end{array}$} \\
\hline & $\mathrm{E} X-21$ & 130 & & \\
\hline & $\begin{array}{l}\mathrm{EX}-23 \\
\mathrm{EX}-25\end{array}$ & 160 & & \\
\hline Kill & $\begin{array}{c}\text { GAMBRO } \\
\text { (optima) } \\
\text { R P }-5 \\
\text { VIVACELL } \\
\left(1.0 \mathrm{~m}^{2}\right)\end{array}$ & 130 & \multirow{2}{*}{$\begin{array}{l}\text { 2回 (※3回)に分けて rins } \\
\text { しその際 dialyser を一度 } \\
\text { 反転させ blood inletsideを } \\
\text { 下にし、へパリン生食を、 } \\
\text { blood inletside に集めて } \\
\text { から再度 dialyser 反転さ } \\
\text { せてrinsする。 }\end{array}$} & \multirow[t]{2}{*}{$\begin{array}{c}15.0 \\
(\min )\end{array}$} \\
\hline Argonne & HEMOCLEAR & $160 \%$ & & \\
\hline H F K & $\begin{array}{l}\text { C D E F K } \\
\text { (Model-5) } \\
\text { A H F K } \\
(\mathrm{K}-11) \\
\text { A H F K } \\
(\mathrm{K}-12)\end{array}$ & 100 & $\begin{array}{l}3 \text { 回に分けて rinsし } 2 \text { 回目 } \\
\text { より arterial air trapに充 } \\
\text { 分圧をたくわえその圧で一 } \\
\text { 気に fiber内の血液を回収 } \\
\text { する操作をくりかえす。 }\end{array}$ & $\begin{array}{l}13.0 \\
(\min )\end{array}$ \\
\hline
\end{tabular}

表 । 各種 dialyser の返血方法

返血方法, コイル型ダイアライザーでは，表 1 のごと く, 透析面積に応じて 100 から $130 \mathrm{ml}$ のヘパリン生食を 2 回に分けてリンスした，介助者を付けて，血液の流れ をスムーズにするため，コイルを回転させたり，デット スペースに血液が停滞しないように努めた。キール型ダ イアライザーは $130 \mathrm{ml}$ のヘパリン生食を 2 回に分けて リンスした。このタイプのダイアライザーは，比較的ダ 
イアライザーの両端や角に残血が多いが, メンブラン全 体にヘパリン生食が行き渡りリンスできるように，ダイ アライザーを半転させ, ブラッドインデットサイドを下 にして，へパリン生食をブラッドインデットサイドに一 度集め, 再度ダイアライザーを半転させ, 正規の位置に 戻し，十分時間をかけて返血した．HFK は $100 \mathrm{ml}$ のへ パリン生食を 3 回に分けてリンスし，2回目よりは静脈 側エアトラップの下をクランプし，血液ポンプの回転を 高速にしてェアトラップに圧を十分蓄光, 開放すること により，その圧でファイバー内残血を一気に回収する操 作を 10 数回繰り返す方法を用いた.

残血量測定方法, $51 \mathrm{Cr}$ を用いて測定した. あらかじめ 赤血球に $51 \mathrm{Cr}$ をラベルしてあるペーシェントより, 採 血したコントロール血液 $1 \mathrm{ml}$ 中の $51 \mathrm{Cr}$ と透析終了後 のダイアライザー内 $51 \mathrm{Cr}$ とを，アロカ社製ダイリュー ションコンピュータにてカウントし, 両者を比較, 残血 量を算出した。基礎実験として回収率試験を表 2 のごと き方法で行ったところ, $97 \pm 7 \%$ 高い回収率であった.

表 3 は, RBC, Hb, Ht, $51 \mathrm{Cr}$ を用いた各検査方法で同 一ダイアライザーの残血を測定したものである. RBC, $\mathrm{Hb}, \mathrm{Ht}$ の測定方法では, リンスできない部分や凝結し たものの測定は不可能であり, $51 \mathrm{Cr}$ を用いた測定に比べ

\begin{tabular}{|c|c|c|c|c|}
\hline & $\begin{array}{l}\text { Blood } 1 \mathrm{ml} \text { } \\
{ }^{51} \mathrm{Cr}[\mathrm{CPM})\end{array}$ & $\begin{array}{c}\text { Dialyser 内 } \\
{ }^{51} \mathrm{Cr}[\mathrm{CPM}]\end{array}$ & $\begin{array}{l}\text { 残 血 量 } \\
\lceil\mathrm{ml} 〕\end{array}$ & $\begin{array}{r}\text { 回収 率 } \\
{[\%]}\end{array}$ \\
\hline 1 & 312 & 287 & 0.92 & 92 \\
\hline 2 & 312 & 328 & 1.05 & 105 \\
\hline 3 & 312 & 295 & 0.95 & 95 \\
\hline 計 & & & $0.97 \pm 0.07$ & $97 \pm 7$ \\
\hline
\end{tabular}

表2 回収率

blood $20 \mathrm{ml}+{ }^{51} \mathrm{Cr} 100 \mu \mathrm{ci}$ のうち $1 \mathrm{ml}$ CDHFK Model-5 のblood side に注入して Aloka 社製の dilution computer にて Dialyser 内の ${ }^{51} \mathrm{Cr}$ を count した

\begin{tabular}{|c|c|}
\hline $\mathrm{RBC}$ & $\begin{array}{l}\text { 1. 凝血したものはCount できない } \\
\text { 2. Rinsできない部分の測定は不可能 }\end{array}$ \\
\hline $\mathrm{Hb}$ & $\begin{array}{l}\text { 1. 凝血したものは测定不可能 } \\
\text { 2. Rinsできない部分の測定不可能 } \\
\text { 3. Rinsされた液の濁り老測定してしまう }\end{array}$ \\
\hline $\mathrm{Ht}$ & $\begin{array}{l}\text { 1. Rins できない部分の測定は不可能 } \\
\text { 2. Rins された液中に血球成分が少なすぎ } \\
\text { て誤差が大きい }\end{array}$ \\
\hline
\end{tabular}

表 3 残血量測定における検查方法の問題点

\begin{tabular}{|c|c|c|c|c|}
\hline & $\mathrm{RBC}$ & $\mathrm{Hb}$ & $\mathrm{Ht}$ & ${ }^{51} \mathrm{Cr}$ \\
\hline 1 & 0.17 & 0.68 & 0.37 & 1.02 \\
\hline 2 & 0.32 & 0.87 & 0.33 & 1.00 \\
\hline 3 & 0.43 & 0.71 & 0.34 & 0.93 \\
\hline 4 & 0.22 & 0.47 & 0.26 & 0.62 \\
\hline 5 & 0.22 & 0.85 & 0.33 & 0.51 \\
\hline 6 & 0.21 & 0.51 & 0.18 & 1.16 \\
\hline
\end{tabular}

単位〔 $\mathrm{ml} 〕$

表 4 検查方法による残血量の比較 dialyser : EX-21, EX-25

\begin{tabular}{|l|c|}
\hline \multicolumn{1}{|c|}{ Dialyser } & 残 血 量 (ml) \\
\hline $\mathrm{E} \mathrm{X}-20$ & $0.88 \pm 0.03$ \\
\hline $\mathrm{E} \mathrm{X}-21$ & $0.75 \pm 0.38$ \\
\hline $\mathrm{E} \mathrm{X}-23$ & $1.12 \pm 0.41$ \\
\hline $\mathrm{E} \mathrm{X}-25$ & $1.50 \pm 0.31$ \\
\hline GAMBRO(optima) & $0.66 \pm 0.19$ \\
\hline R P -5 & $0.96 \pm 0.28$ \\
\hline VIVA CELL $\left(1.0 \mathrm{~m}^{2}\right)$ & $1.30 \pm 1.00$ \\
\hline HEMOCLEAR $※$ & $2.21 \pm 0.50$ \\
\hline CDHFK(model-5) & $2.58 \pm 2.50$ \\
\hline AHFK(K-11) & $1.33 \pm 1.03$ \\
\hline AHFK(K-12) & $0.57 \pm 0.23$ \\
\hline
\end{tabular}

表 $5{ }^{51} \mathrm{Cr}$ による各種 dialyser の残血量

$$
\mathrm{n}=10 ※ \mathrm{n}=9
$$

低值を示した，更に Hb では, リンス液の濁りを測定し てしまい, 検査方法としては問題があった。 また Htで は, リンス液中の血球成分が少な過ざて, 測定結果はす ベて誤差範囲内であった. $51 \mathrm{Cr}$ による測定が理論的には 一番よいて思われるが， RI 設備のない施設に拈いて， 日常, 簡易的に残血量をチェックするには，これらの問 題点を踏まえた上で， RBCによる測定が検査方法 上, $\mathrm{Hb}, \mathrm{Ht}$ による測定より有利と考える.

結果, 表 4 の返血方法及び $51 \mathrm{Cr}$ による残血量の測定 で，表 5 のごとき成績を得た。残血量が最も少ないダイ アライザーは旭 $\mathrm{HF}, \mathrm{K}-12$ の平均 $0.57 \mathrm{ml}$ で, 最も多い ダイアライザーはコーデス $\mathrm{HF}$ モデル 5 の平均 $5.58 \mathrm{ml}$ であった．臨床的に見ても，残血量は極力抑光るべく努 力しなければならないが，そのためには，技術的な問題 のほかに，我々スタッフが，透析患者につきまとう貧血 といら合併症を常に頭に入れ，意識して十分時間をかけ 
て返血作業を行う必要がある. 今回, 残血量の多かった ダイアライザーについては, 残血量を $1 \mathrm{ml}$ 程度以下に抑 えるべく，返血方法やリンス量を再検討するつもりであ る. と同時に, ダイアライザーの構造や製造の問題で, 残血量の多いダイアライザーについてはこれらの改良が 望まれる。

川ロ 次は 24 席の京浜病院腎センターの田中さんに お願いします。

田中 透析終了時, HFK では症例によってはかなり の残血，目諸まりが認められます。へパリン量を増加す れば残血は減りますが，過量のへパリンは, 出血, 心包 炎などの原因となります，当センターでは HFK のへパ リンを初回 5,000 単位, 以後, 毎時 1,000 単位ずつ追加 しています，最近，鼻出血や消化管出血のため輸血をせ ざるを得ない 2 症例を経験しましたので，ヘパリン使用 量につき再検討しました.

出血例 2 例, 及び他の症例 8 例, 延べ 164 回, 透析終 了後 HFK の断端の目詰まり率を実測し, 初回へパリン 量との関連を見ました（図 1 ). 透析時間は週 3 回 5 時間

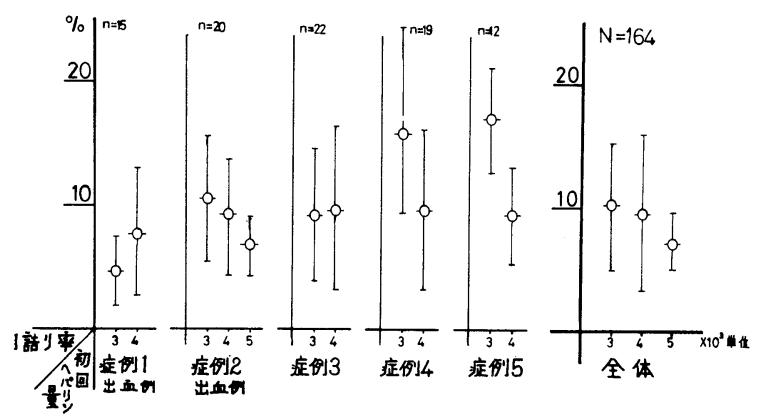

図、“初回ヘパリリ贯による目詰り革の变化

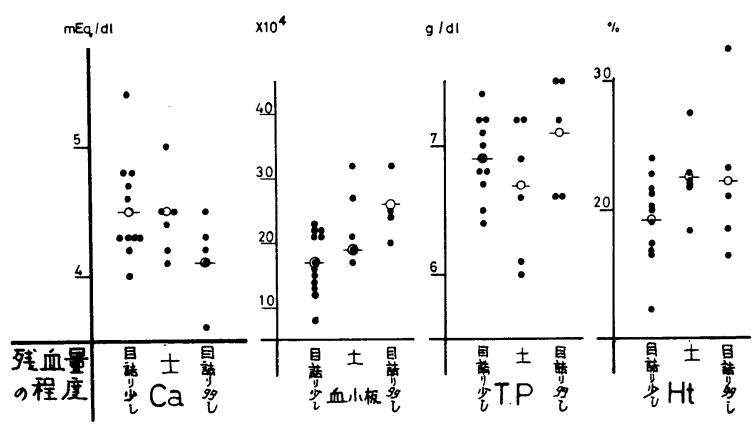

図 2 球血の程店との相閒
です．出血例では初回へパリン量を変えても目詰まり率 はほぼ $10 \%$ 以下で, 逆に目詰まりの多い症例は初回へパ リン量に目詰まり率が関連することがわかりました。ま た目詰まりの多い症例では個人差があり，へパリン量を 多くしてもきれいに拔けないことが経験されました。

更にへパリン感受性テストを行い， ヘパリン量を変え てみましたが，実際の経験とは必ずしも一致しません。 そこでダイアライザーの目詰まりに及ぼす影響を血液凝 固機転各因子との関連で検討しました。測定項目は総蛋 白量, $\mathrm{Ht}, \mathrm{Ca}$, 血小板数, プロトロンビン時間, フィブ リノーゲン及びフィブリン分解物 (FDP), フィブリノー ゲン及び FDP は FDPL テストを使用しました。諸因子 を目詰まりの多少で症例を 3 つの群に分け，比較検討し たものです（図 2 ). 目詰まりの良否は, 約 2 力月, 終了 時に残血の程度を調べ，区分化しました，総蛋白量は 各群に差がなく, $\mathrm{Ca}, \mathrm{Ht}$ はバラつきを除くと各群の差は 著明でなくなり，血小板数のみ関連があることがわかり ました。

プロトロンビン時間は相関不明で，フィブリノーゲン の正常值 200 から $400 \mathrm{mg}$ Al でありますが, 目詰まりの 少ない群は $350 \mathrm{mg}$ Al 以下であり，また目詰まり群では フィブリノーゲの少ないものと多いものの 2 つに分かれ でります.FDP 量と逆の相関が認められます（図 3 ).

図 4 は各症例と FDंP, フィブリノーゲン量との関連を 見たものであります。は抜けやすい症例，・は残血の 多い群，×印はその中間です，図に明らかなごとく，目 詰まり率が少ないものはフィブリノーゲンが少なく，か つFDP が増加して撤, 逆にフィブリノーゲンが多く ても FDP が多いもの, 又はフィブリノーゲンが少なく てもFDP が低いものなどは目詰まり率が高いことがわ かりました。

以上, ダイアライザー内凝血又は残血の程度には, 血 小板のほかフィブリノーゲン及び FDP が関与している こと, ヘパン使用量及びウロキナーゼ使用の決定に は, FDP テストの測定法は極めて簡単ですから, 本テス トの成績を参考するのが良いと考えます.

現在私どものセンターで使用している基準を示しまし た(表 1 ). 1 が, ダイアライザーの目詰まりは血小板数, フィブリノーゲン及び FDP 量に影響されること. 2 , へ パリン使用量及びウロキナーゼ使用の可否は, フィブリ ノーゲン及び FDP 量が参考になる. HF の場合, フィブ リノーゲンが $300 \mathrm{mg} / \mathrm{dl}$ 以下であり, FDP が $5 \mu \mathrm{g} / \mathrm{ml}$ 以上の場合, ヘパリン初回量を 3,000 単位としています。 またフィブリノーゲンが $300 \mathrm{mg} / \mathrm{dl}$ 以上であり, FDP が $5 \mu \mathrm{g} / \mathrm{ml}$ 以下の場合は, 初回ヘパリン量を 4,000 単位 とし，ウロキナーゼを使用しています。 

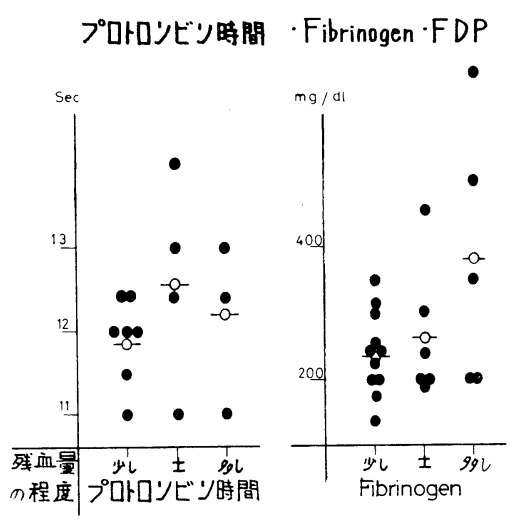

\section{との相閊}

図 3

\section{FDPおよU゙フィブリノーゲンと目詰リ率との相䦰}

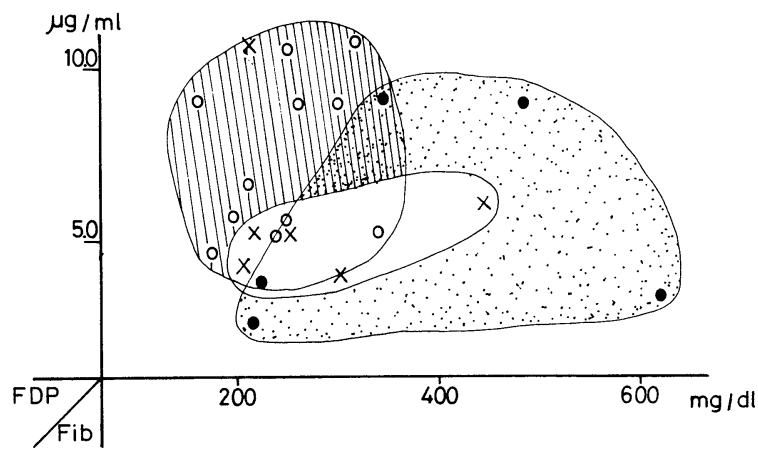

図 4

1. ダイアライザーの目詰りは, 血小板数, フィブリノー ゲン（Fib）扎よび FDP 量に影響される.

2. ヘパリン使用量およびウロキナーゼ使用の可否 は, Fib 拈よび FDP 量が参考になる。

3. HFK (ウェット型)

$\mathrm{Fib} 300 \mathrm{mg} / \mathrm{dl} \downarrow$ 初回ヘパリン量 $3 \times 10^{3}$ 単位

FDP $5 \mu \mathrm{g} / \mathrm{ml} \uparrow$

Fib $300 \mathrm{mg} / \mathrm{dl} \downarrow$ 初回ヘパリン量 $4 \times 10^{3}$ 単位

FDP $5 \mu \mathrm{g} / \mathrm{ml} \uparrow$ ウロキナーゼ併用

\section{表 1 結 語}

川ロ ここで残血についての演題が終わりますので, 時間を少しいただきまして，まとめのディスカッション をしたいと思います。

今発表されたことをまとめてみますと，1つは残血量 の測定の問題と測定の方法と残血量々のものの問題, 量 についての検討と，も51つは返血の方法で，これは生 食とかエアとかアミノ酸を加えたグルコースとか, それ
を 2 次， 3 次とやった方がいいとか，余り変わらないと いらような技術上の問題と, 最後の演題にありましたよ らに, ヘパリンの使用量と残血の関係，こういら 3 つの 分野に大別でさると思いますけれども，演者間でそれぞ れディスカッションされること，また御質問されること がございましたら㹉願いします。

実際の残血量について，同じよらなダイアライザーを 使って私のところはそんなによくないとか, もっときれ いになるとかということがございましたら…...

では，返血のときに何を使って返血したらいいかとい うことでございますけれども，この問題について私はこ う思う，我々の方法はこれが一番だといら自己主張とい らか, 自分の主義を持ってられる方がいたら発表してい ただきたいんですが。

森井（東海クリニック） 23 番のところで, 各種のダイ アライザーの返血方法のところで，M 5 が相当残血が残 ることを示されて扣りましたけれども，東海に拈いて， 旭の 12，0 1，M 5 を中心に使って特りますけれども， 一応返血方法は患者とナースがチームを組んで返血をや るために, ナースが 1 人ですので, 空気混入の関係から 危険率が高いために， $5 \%$ ブドウ糖 $250 \mathrm{ml}$ の返血方法を 使って扣ります。で，現在のところは大体返血状態はよ くて, Mt が $30 \%$ 以上の患者が，総数 55 名中約半分以 上, Ht を維持して挹ります.M 5 で特に返血の悪い方で すけれども,大体 $\mathrm{Ht}$ が $38 \%$ から 44\%の患者に多くあり ますので，その患者には臨機応変にヘパリン単位を，今 はプライミングに 2,000 単位使っておりましてその患者 には 10,000 単位を使いまして 24 時間プライミング後の 放置をして扬ます。その関係もありますけれども，そ のデータよりも少しいい方法が東海の方においてはデー タに出ておりますけれども.

川ロ 今の質問に関する答といらか, ディスカッサー は, 23 番の方と 24 番の方とあると思いますけれども，い かがでしょらか。

小林ファイバーの中に入っている残血量に関して は，従来は余り正確に測定できる方法というものがな かったように思います。従来うちで測定していたのは， 実際のファイバーの本数を 1 本 1 本一これも大体にし かなりませんけれども，数えて，それの 1 本当たりのプ ライミングボリュームを掛けてたわけですけれども，今 回, 赤血球寿命を測るという目的で, ${ }^{51} \mathrm{Cr}$ を各患者にラ ベルしたということがありまして，ダイアライザーをリ ンスするとかしないとかといらことじゃなく，ダイアラ イザーごと ${ }^{51} \mathrm{Cr}$ の数をカウントするということで，ま ずュルディスのファイバーは残血量が多いと思います. それと，これは手技の問題ではなくて，1つは製造過程 
でのファイバーの切断の仕方とかそういったところに問 題があるんじゃないかなと思います，今後，返血方法を 検討してみます。

川ロついでにと言っては何ですけれども, 残血量の 測定について，今まで ${ }^{51} \mathrm{Cr}$ とアルブミンと赤血球を使 用すると，3つの方法について発表されたわけですけれ ども，その各々の方法について，三笠市立病院の方が幾 つかの問題点を比較して挙げて打られますけれども，ア゙ ルブミンを利用して残血を求めておられる方は，埼玉県 腎センターの青野さんですか，その方は討論をされるこ とはございますか。 ${ }^{51} \mathrm{Cr}$ 必ずしもクリニカルにしょっ ちゅらできるわけではないということで，アルブミンは 非常にいい方法ではないかと思うんですが，この問題に ついて, 逆に市立三笠病院の小林さん，質問されること はございるすか.

小林 アルブミンによる残血量の測定に関しては，今 回は我々検討して打りませんし，僕自身も持ってきませ んでしたのでわかりませんけれども，今後検討しまして よい方法であれば，さっき言ったように ${ }^{51} \mathrm{Cr}$ はそう使 壳るものではないので，アルブミンについても検討して みたいと思います。

川口 24 番の京浜病院腎センターの田中さんは, 今ま で非常に経験的にやっておられたことが，血小板とフィ ブリノーゲンと FDP を測定して検討してみると非常に 合うという，我々にとっては安心するようなデータを見 せられたわけですけれども，このことについてどなたか 質問される方はいらっしゃいませんでしょらか.

では, 一応このセクションは次の 25 番から 32 番まで を終わりまして，もう一度時間がありましたら討論した いと思います。

沢西 では, 25 席の西新宿病院の雨宮さんに打願いし ます。

雨宮 通常, 原水には無機物, 有機物及び溶存ガス等 が，地理的，季節的，また天候によって変化して含まれ る.このため, 透析用に使用する場合には適当な水処理 を行うことが望ましい，しかしながら，一定しない組成 を持つ原水の水質を改善しようとするのに単純な装置で 行うのは非現実的である.

この点, 当院では透析に最適な水を得る目的で, 逆浸 透法による純水装置を設置している，図 1 は，本装置の 構成図であり, 表 1 は, この逆浸透装置に使われている アセテート系半透膜, ダイセル DRS 97 の分離特性を示 したものである，本装置内には更にイオン交換樹脂，細 菌繁殖を防ぐための紫外線殺菌灯，また再使用台には $0.2 \mu$ の精密フィルター等を付け加えてある.

表 2 は, 水の細菌検査の結果である. 本装置のごとく

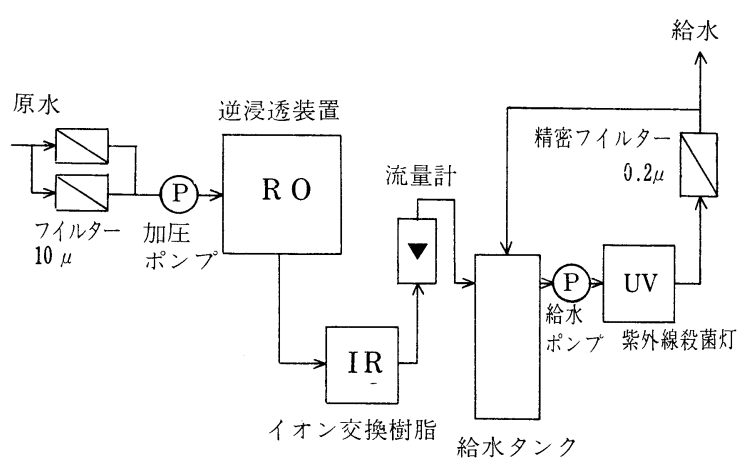

図，逆浸透装置構成困 (MOLSEP)

(1) 無機物

\begin{tabular}{|c|c|c|}
\hline \multicolumn{2}{|r|}{ 化学名 } & 分離 $(\%)$ \\
\hline \multicolumn{2}{|c|}{ 1）陽イオン $\left(\mathrm{Na}^{+}, \mathrm{Ca}^{++}, \mathrm{Cd}^{++}, \mathrm{Hg}^{+}, \mathrm{NH}_{4}{ }^{+}\right.$など$)$} & $80 \sim 99$ \\
\hline \multicolumn{2}{|c|}{ 2) 陰イオン $\left(\mathrm{Cl}^{-}, \mathrm{SO}_{04}^{--}, \mathrm{CN}^{-}, \mathrm{Fe}(\mathrm{CN})_{6}^{---}\right.$など） } & $90 \sim 99$ \\
\hline \multicolumn{3}{|l|}{ (2) 有機物 } \\
\hline \multicolumn{3}{|c|}{ 分子の大きさ } \\
\hline 1）分子量 & 100以下のもの & 選択特性 \\
\hline 2）分子量 & 100 200程度のもの & $70 \sim 98$ \\
\hline 3）分子量 & 200 以上のもの & 100 \\
\hline \multicolumn{3}{|l|}{ (3) 溶存ガス } \\
\hline \multicolumn{2}{|c|}{ 化学名 } & \\
\hline \multicolumn{2}{|c|}{ 1）炭酸ガス（ $\left.\mathrm{Co}_{2}\right)$} & $30 \sim 50$ \\
\hline \multicolumn{2}{|c|}{ 2）塩素ガス $\left(\mathrm{Cl}_{2}\right)$} & $30 \sim 50$ \\
\hline
\end{tabular}

但し，膜はダイセル DRS-97を使用した場合である。

表। MOLSEPの分離特性

\begin{tabular}{|c|c|c|c|c|c|c|}
\hline 回 数 & 原 & 水 & RO & IR & 給 & 水 \\
\hline 1 回目 & 陰 & 性 & 陰 性 & & 陽 & 性 \\
\hline 2 回目 & 陰 & 性 & 陰 性 & & 陽 & 性 \\
\hline 3 回目 & 㓌 & 性 & 陰 性 & 陽 & 陰 & 性 \\
\hline
\end{tabular}

№ 2 は次带塩素酸による消毒結果

№3はホルマリン $(3 \%)$ による消毒結果

表 2 細菌結果

安全な水処理機構をもって行っても, 途中の給水ライン に問題があると, 細菌の発生が見られるケースもあり得 ることを示している．この対策として，配管内，給水夕 ンク内, すべてをホルマリン等で定期的に消毒する必要 があると思われる。

表 3 は，水質試験の結果である，給水の比抵抗值は平 均 2 から $3 \mathrm{M} \Omega / \mathrm{cm}$ の水質状態を保ち，かつウイルスフ 


\begin{tabular}{|c|c|c|c|}
\hline 分析項目 & 原 水 & RO & 給 水 \\
\hline アンモニア性窒素 & 不 検 出 & 不 検 出 & 不検 出 \\
\hline 亜硝酸性窒素 & 不 検 出 & 不 検 出 & 不検 出 \\
\hline 硝酸性窒素 & 10 以下 (ppm) & 10 以下 $(\mathrm{ppm})$ & 10 以下 $(\mathrm{ppm})$ \\
\hline 塩素イオン & $38 \quad(\mathrm{ppm})$ & $20 \quad(\mathrm{ppm})$ & $(\mathrm{ppm})$ \\
\hline カルシウム硬度 & 38 & 0 & 0 \\
\hline マグネシウム硬度 & 38 & 36 & 34 \\
\hline 銅 & $0 \quad(\mathrm{ppm})$ & $0 \quad(\mathrm{ppm})$ & $(\mathrm{ppm})$ \\
\hline 鉄 & $0.14 \quad(\mathrm{ppm})$ & $0.03(\mathrm{ppm})$ & $0.03(\mathrm{ppm})$ \\
\hline マン ガン & $0 \quad(\mathrm{ppm})$ & $0 \quad(\mathrm{ppm})$ & $0 \quad(\mathrm{ppm})$ \\
\hline 亜 & $0.7 \quad(\mathrm{ppm})$ & $0.7 \quad(\mathrm{ppm})$ & $0.7 \quad(\mathrm{ppm})$ \\
\hline 鉛 & $0 \quad(\mathrm{ppm})$ & $0 \quad(\mathrm{ppm})$ & $0 \quad(\mathrm{ppm})$ \\
\hline 総硬 & 82 & 36 & 34 \\
\hline $\mathrm{PH}$ & 7.1 & 5.9 & 5.9 \\
\hline
\end{tabular}

表 3 水質試験結果

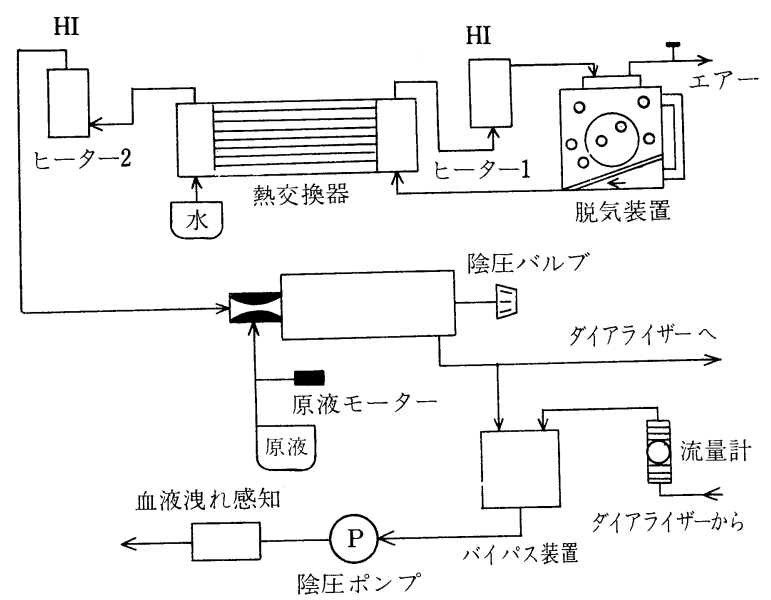

図 2 十イコトロン構成図

リー, パイロジュンフリー, Ca フリーとする高純度の精

製水を得ている。

次に供給装置の消毒についてであるが，まず消毒法と しては，次亜塩素酸及びホルマリンによる薬液消毒，あ るいは $85^{\circ} \mathrm{C}$ 前後で行ら熱湯消毒が広く一般に行われて いる. 当院では更に第 3 の消毒法として, 蒸気のみで自 動的に完全消毒を行う, つまりオートクレーブ内蔵の個 人用シングルパス方式の供給装置を使用中である. そこ で, 三者の消毒効果の比較と, 特に蒸気消毒の効果につ いて報告する.

図 2 は, この装置の内部の構成図を示したものである. な抏この装置はノルウェーのナイトロン社が開発した
ものである，原理的にはオートクレーブ方式をとってお り，消毒時は閉鎖回路が組まれ，内部にある $200 \mathrm{ml}$ 程度 の水がヒーター 1 と 2 によって十分加熱され，更に $1 \mathrm{~kg} / \mathrm{cm}^{2}$ の圧力によって $120^{\circ} \mathrm{C}$ の蒸気を作り上げ，約 30 分間再循環を繰り返して消毒を完了する. 非常な高温 であるために，内部のチューブ等はテフロン及びステン レス 304，316が使用されている．また消毒後の装置内の 無菌テストの結果は三者共に陰性であり，したがって消 毒効果の点でははっきりした差はないが，ここで蒸気消 毒の利点を挙げてみると，1，消毒用の水が汪とんど不 要である. 2 ，消毒時間が短い。 3 . 操作手順が簡単で あり，自動的に完了する．また欠点としては，消毒後再 使用するまで相当の時間を要するなどである.

結論, 慢性血液透析に使用する水は, 原水の組成によっ て適当な水処理が必要である。その際，逆浸透装置ある いは軟水化装置が望ましい，特にパイロジェン等の問題 を考慮した場合，前者は透析に最適なウォータートリー トメントであると思われる，また供給装置の消毒法にお いては, 今後オートクレーブ方式による蒸気消毒の採用 が大いに期待される.

沢西 次に幸町診療所人工腎センターの服部さんに拉 願いします。

服部 ウェットタイプの HFK は優れたダイアライ ザーですが，準備段階でのホルマリン除去に 1 つの厄介 な問題があります。そこで私たちは最近，西ドイッのコ ロン大学病院でも始められている HFK の迅速洗浄法 について検討を加えましたので，その結果を報告いたし ます.

表 1 のよに, 従来の洗浄方法では, 残留ホルムアル デヒド濃度を $10 \mathrm{ppm}$ 以下にするためには，私たちの測 定では, 生食 $2,000 \mathrm{ml}$ で約 35 分の操作時間を要し,しか も透析室内がホルマリンガスで污染される危険もありま す。一方，迅速洗浄法は透析液側のホルマリンは洗浄で 除去しながら，同時に血液側のホルマリンはホルムアル デヒドが分子量 30.03 で，透析されやすい性質を利用し て，透析によって除去するもので，操作は表 1 に示すと 扣りで，透析液側のホルマリンは捨てることなく，供給 装置に接続し, $37^{\circ} \mathrm{C}$ の透析液を毎分 $500 \mathrm{ml}$ で流します. このとき陰圧は掛けません。同時に血液回路にへパリン 加生食を充てんして, HFK に接続し, 動静脈回路の先端 を連結し，ループ状の閉鎖回路とします。次に毎分 $350 \mathrm{ml}$ で血液側のホルマリン液を送血ポンプにて再循 環させます. 12 分後には残留ホルマリン濃度 $10 \mathrm{ppm}$ 以 下となり，全操作は15 分で終了いたします。前もってホ ルマリン液を排除する必要もないので，ホルマリンガス による透析室の污染もありません。 
カトKのホルマリン除去法

Cordis-Dow原法 (従来の洗浄法)

透析液側の木儿刏除去 (1分)

透析液侧の洗浄

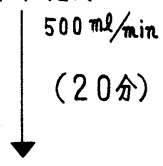

血液側の洗浄

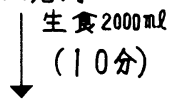

ヘパリン加生食充填

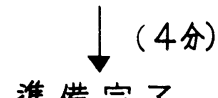

準備完了

门要時閒糊 35 分 表

そこで，私たちがこの洗浄条件を決定する根拠となっ たインビトロの実験データを示してみたいと思います。 なお，実験に使用した HF はすべて C-DAK モデル 4 であります。

図 1 は，私たちが測定したホルムアルデヒドのクリア ランス曲線ですが, 血液量毎分 $350 \mathrm{ml}$ で，ほぼ最高値の $170 \mathrm{ml} / \mathrm{min}$ に達します. そこで血液側ホルマリンの透析 除去を目的とした送血ポンプの再循環速度は, 毎分 $350 \mathrm{ml}$ といたしました。

この方法で洗浄温度, 透析液側の予備洗浄時間, 透析 液側あるいは血液側のホルマリン液をあらかじめ抜き取 るなどの条件を変えて, 10 分後の残留ホルマリン濃度を

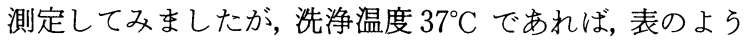
に他の条件を変えても有意の差は見られません。

そこで, 洗浄温度 $37^{\circ} \mathrm{C}$ として, この迅速洗浄法により 残留ホルマリン濃度を経時的に 20 分まで測定したのが この図 2 で, 残留濃度は洗浄開始後 $10,000 \mathrm{ppm}$ あったも のが，時間の開始と共に急激に減少いたします，10ppm 以下を目標とすれば 12 分で達成されます.

次に臨床データですが, 従来の洗浄方法を 44 名の患者 に延べ 4,628 回, 迅速洗浄法を 52 名の患者に 3 力月間, 延べ2,023 回実施した結果を比較したのが表 2 でありま す. 急性毒性, 発熱反応, 慢性毒性について, 両者の洗 浄法に有意な差はなく，また漏血率，残血量といった $\mathrm{HF}$ そのもの元影響も両者では汪とんど差が認められませ ん.

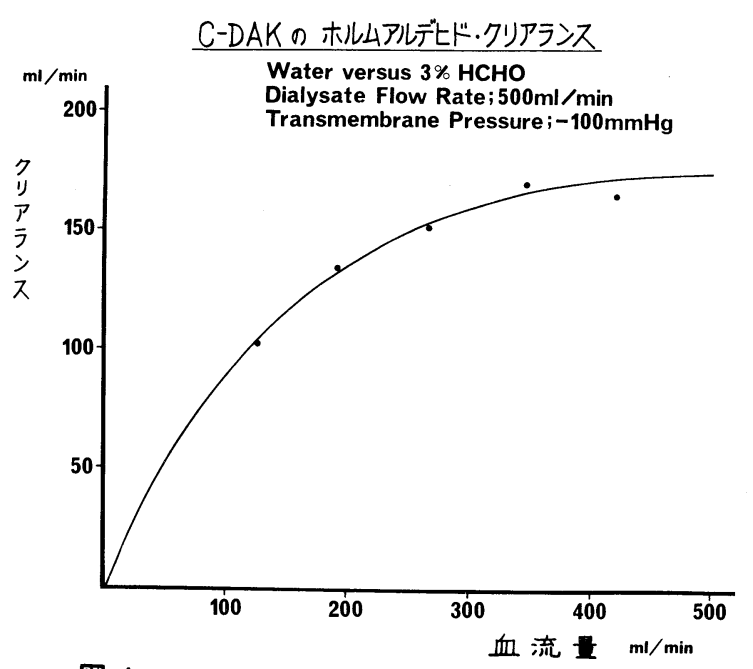

図 I

\begin{tabular}{|c|c|c|}
\hline & 従来の 洗浄法 & 迅速洗浄法 \\
\hline $\begin{array}{l}\text { 残留ホルマリン } \\
\text { 澧 度 } \\
\end{array}$ & $8.3 \pm 3.9 \mathrm{PPM}$ & $8.8 \pm 5.2 \mathrm{PPM}$ \\
\hline $\begin{array}{c}\text { 急性机マリン } \\
\text { 反 店 }\end{array}$ & $\begin{array}{l}0.06 \% \\
(3 / 4628) \\
\end{array}$ & $\begin{array}{l}0.05 \% \\
(1 / 2023) \\
\end{array}$ \\
\hline 発嗞反応 & $\begin{array}{r}5.6 \% \\
(260 / 4628) \\
\end{array}$ & $\begin{array}{r}2.6 \% \\
(53 / 2023) \\
\end{array}$ \\
\hline GOT & $14 \pm 1 \underbrace{}_{n=257}$ & $17 \pm 19_{n=301}$ \\
\hline GPT & $21 \pm 22$ & $\begin{array}{r}20 \pm 26 \\
n=301\end{array}$ \\
\hline$T P$ & $7.1 \pm 0.6$ & $\begin{aligned} 7.1 \pm 0.5 \\
n=635\end{aligned}$ \\
\hline$A / G$ & $\begin{array}{r}1.95 \pm 0.33 \\
n=222 \\
\end{array}$ & $\begin{array}{r}1.75 \pm 0.35 \\
n=292 \\
\end{array}$ \\
\hline イマト物卜 & $22 \pm 5_{n=570}$ & $21 \pm 6_{n=640}$ \\
\hline 白血球数 & $\begin{array}{r}7627 \pm 3456 \\
n=123\end{array}$ & $7911 \pm 3118$ \\
\hline 漏血率 & $\begin{array}{l}0.5 \% \\
(16 / 3216) \\
\end{array}$ & $\begin{array}{l}0.5 \% \\
(9 / 1782)\end{array}$ \\
\hline 残血点 & $\begin{array}{r}6 \pm 3 m e \\
n=39\end{array}$ & $8 \pm 5 m_{n=32}$ \\
\hline
\end{tabular}

衰 2

$N=44$

$N=52$ 


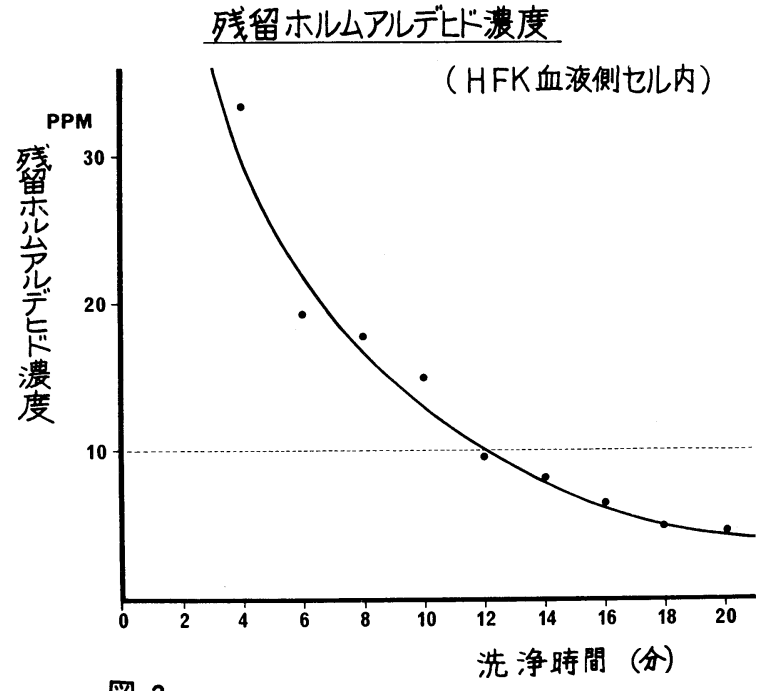

图 2

以上, 迅速洗浄法は, 準備時間 15 分で完了し, 洗浄に 要する生食も $200 \mathrm{ml}$ と少なく, 透析室をホルマリンガス で污染する危険もなく, また操作中, HF を損傷すること もない，安全な方法として推奖できるものと考えられま すのでここに報告いたしました.

沢西 27 席の東京クリニックの松金さんに打願いし ます。

松金 現在市販されている中空糸型ダイアライザーの 消毒法の 1 つとてホルマリンが用いられ, 使用に際し てはホルマリンの完全除去が望まれます。しかし内外の 中空系のホルマリン除去と共に, 線維に浸透しているホ ルマリン除去の問題が残ります.

我々は灌流液側を水道水 $1,000 \mathrm{ml} / \mathrm{min}$ で 2 時間洗浄 し, 血液側を生食水 $500 \mathrm{ml}$ で洗浄した後, 動静脈回路を 閉鎖した循環法を用いて他法と比較検討を加えたので報 告いたします.

ホルマリンの測定方法は図 1 のごとく, アセチルアセ トム法により行い, 発色試薬に検体 $1 \mathrm{ml}$ を入れ摫汼し, $100^{\circ} \mathrm{C} 10$ 分加熱後, $10^{\circ} \mathrm{C} 10$ 分冷却した後, 比色計にて測 定し, 従来の定量法より低濃度の測定が可能でありまし た.

図 2 は, 一般に用いられている洗浄法での変化を見る ため, 30 分灌流液と流した後, 生食水 $2,500 \mathrm{ml}$ にて洗浄 し, 灌流液側を閉鎖, 動脈回路を連絡, 循環させ, ホル マリン濃度を経時的に測定しました。これによると，1， $000 \mathrm{ppm}$ 以上のホルマリンは $500 \mathrm{ml}$ の生食洗浄時には 既に 50ppm, 2,500ml では $3 \mathrm{ppm}$ と除去され, 灌流液側 を閉鎖, 循環を行い, ホルマリン濃度を測定すると, 5 分後 $18 \mathrm{ppm}, 30$ 分後で $30 \mathrm{ppm}, 110$ 分で最高 $35 \mathrm{ppm}$ の 高値を示しました. そこで我々は，このようなリバウン

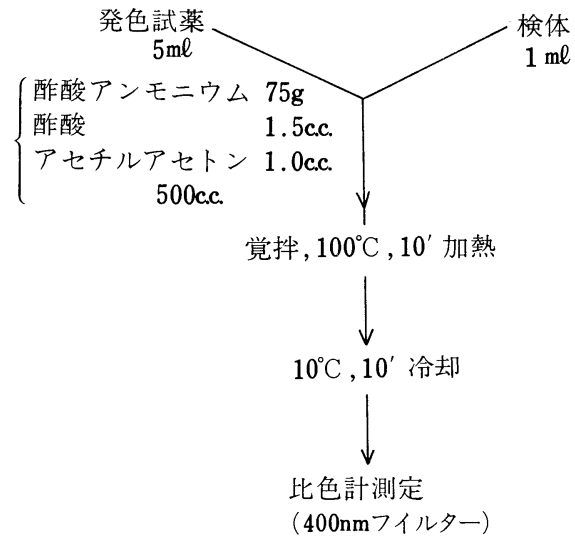

図।ホルマリン 測定方法 (アセチルアセトン法)

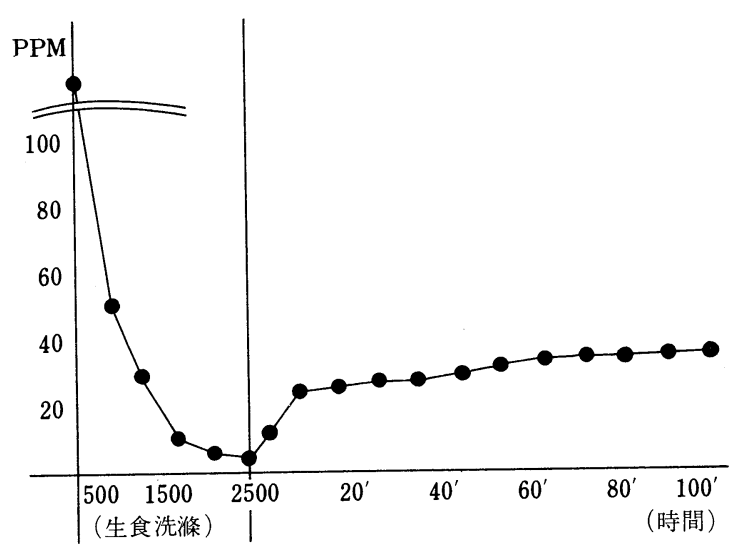

図 2 HFK. M-5

$30^{\prime}$ 灌流液で灌流側洗滌そのまま

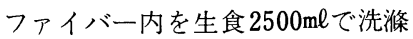

ドを防止するため, 残存ホルマリンを透析する考えを加 味して，次のごとさ方法を検討しました.

スライドは灌流液側を水道水, $1,000 \mathrm{ml} / \mathrm{min} に 2$ 時 間洗浄後, ダイアライザー血液側を $500 \mathrm{ml}$ の生食で洗 い, 動脈回路を連絡, $200 \mathrm{ml} / \mathrm{min}$, 陰陽圧 $150 \mathrm{mmHg}$ で 循環透析を行って, 経時的にホルマリン濃度を測定しま した.な报, 対象例として, $500 \mathrm{ml}$ 生食洗浄後直ちに灌 流液側を閉鎖, 循環させた場合の濃度変化も併せて検討 しました. 図 2 に示すごとく, 循環を併用しない方法で は, 中空糸内生食洗浄後の $40 \mathrm{ppm}$ の残存ホルマリンは, 以後 30 分で最低 $38 \mathrm{ppm} .120$ 分で最高 $50 \mathrm{ppm}$ と漸増の 傾向を示し, 循環を併用した方法では, $500 \mathrm{ml}$ の生食洗 浄後 $40 \mathrm{ppm}$ の残存ホルマリンは循環により5分で $5 \mathrm{ppm}, 30$ 分で $1 \mathrm{ppm}$ と除去され, その後, 灌流液側を 閉鎖し, 循環させ, 経時的変化を見ても, 10 分で $2 \mathrm{ppm}$, 30 分で $6 \mathrm{ppm}, 60$ 分で $6 \mathrm{ppm}, 120$ 分で $9 \mathrm{ppm}$ と, わず 
107

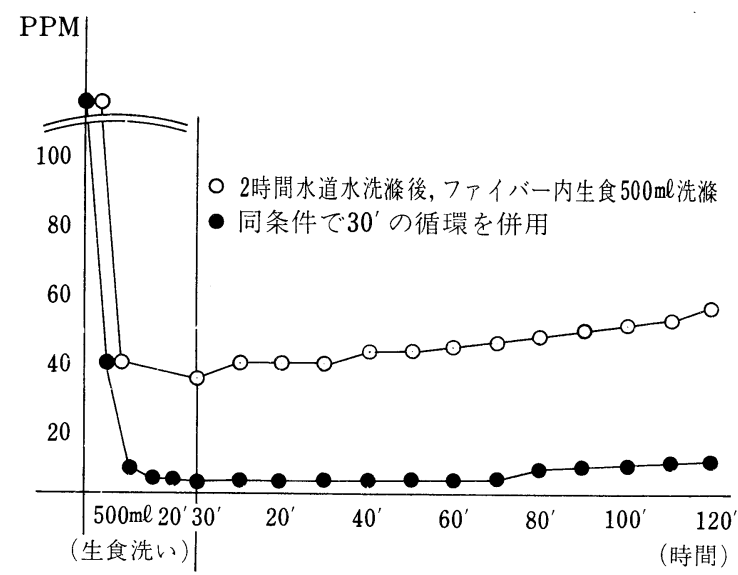

図 2 HFK M-5

かな上昇を見るのみで，明らかなリパウンドを認められ ませんでした。

同様の実験をモデル 4 に行い, $500 \mathrm{ml}$ の生食洗浄にて $50 \mathrm{ppm}$, その後 30 分の循環で $2 \mathrm{ppm}$, 続いて灌流液側閉 鎖後の経時的変化では, 10 分で $2 \mathrm{ppm}, 30$ 分で $10 \mathrm{ppm}$, 60 分で $10 \mathrm{ppm}, 120$ 分で最高 $15 \mathrm{ppm}$ を示したにすぎま せんでした。

以上の結果より, 我々は灌流液側の水道水 1,000 $\mathrm{ml} / \mathrm{min}, 2$ 時間洗浄之, 血液側 $500 \mathrm{ml}$ 生食水洗浄後, 30 分間, 動静脈回路を連絡, 循環させることで, ホルマリン の十分な除去と共に，透析準備時間，手数の簡略化と共 に，生食水の消費を少なくする合理化も併せ志向してい ます。

沢西 28 席の忠岡病院人工透析室の中村さんに北願 いします。

中村 今回私たちは，H F 型ダイアライザーの洗浄方 法とがガスクロマトグラフィ法による残存ホルマリン濃 度について検討を行いましたので, 報告いたします。

従来の洗浄法に準じて灌流液側を水道水で 2 時間洗 浄，その後血液側を生理食塩水 1500 2000mI で洗浄を 行ったときの経時的なホルマリン濃度をみますと，血液 側には洗浄 20 分後でも $31.5 \mathrm{ppm}$ のホルマリンが検出 されております，このことから，従来の洗浄法では生体 内にホルマリン流入及びその副作用の可能性が考えられ ます。そこで私たちは洗浄時間を短縮し, 洗浄効果のよ い方法を検討いたしました。

表 1 は，今回実施した洗浄方法と条件を示して扣りま す. 透析準備室で実施する方法とベッドサイドで準備す る方法に分けまして，タイプAは灌流液側を水道水で血 液側を生理食塩水で同時に洗浄を行う方法，タイプ $\mathrm{A}^{2}$ は灌流液側を水道水で洗浄後, 血液側を生理食塩水で洗 浄する方法, タイプ Bは灌流液側をシングルパスとし,
10 巻 1 号 1977

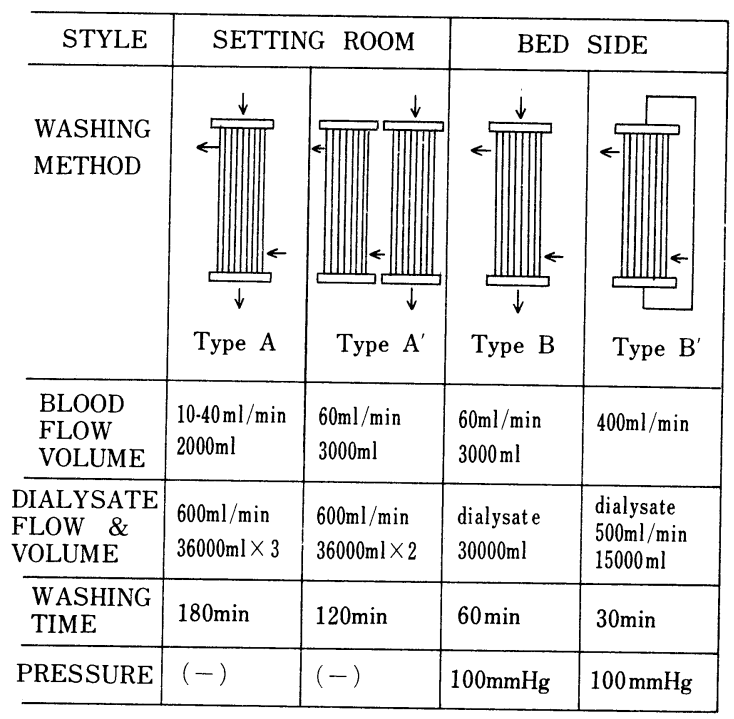

表 I EXPERIMENTAL CONDITIONS \& WASHING METHODS IN HFAK

血液側を生理食塩水で同時に洗浄する方法, タイプ $\mathrm{B}^{\prime}$ は灌流液側をンングルパスとし，血液側はプライミング 量の生理食塩水を再循環させ, 限外濾過される水分量を 補っていく方法です．この 4 つのタイプの洗浄方法と経 時的なホルマリン濃度の変化について観察を行い李し た.

図 1 は, 各洗浄法に打ける灌流液側のホルマリン対数 濃度の経時的変化を示して抢ります。その結果, 灌流液 側と血液側を同時に洗浄する方法が優れており，洗浄 20 分から 30 分でホルマリン濃度は検出でさなくなります。

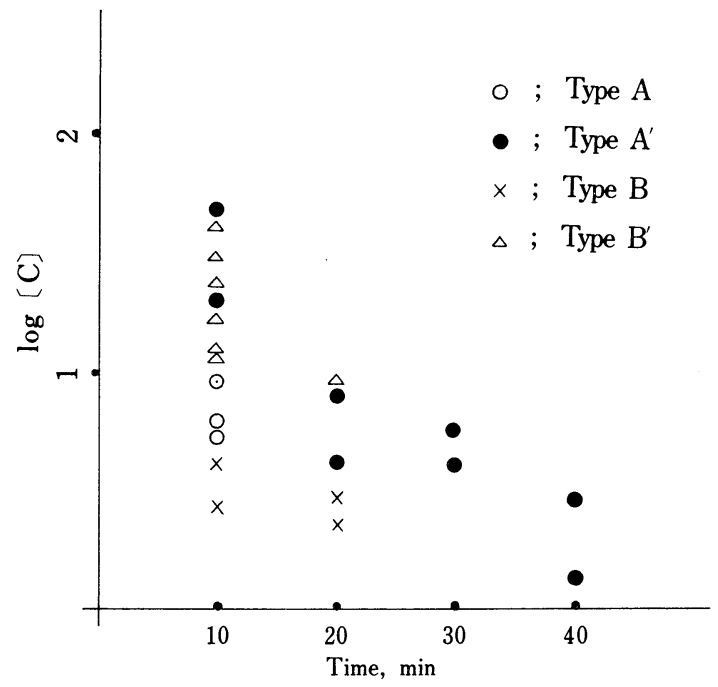

図 I FORMALDEHYDE CONTENT IN DIALYSATE SIDE AFTER WASHING OUT 


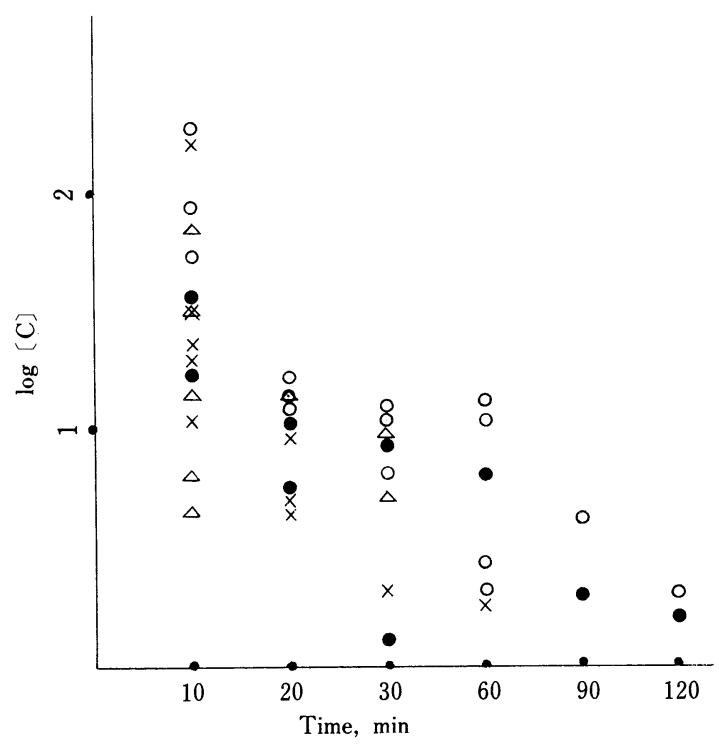

図 2

FORMALDEHYDE CONTENT IN BLOOD SIDE AFTER WASHING OUT

図 2 は血液側ホルマリン濃度の変化を示しています. 最も早くホルマリンが除去されるのは×印，すなわち灌 流液側シングルパス, 血液側生理食塩水の同時洗浄の $\mathrm{B}$ タイプで，次には $\Delta$ 印の再循環式であります．従来の洗 浄方法に準ずるタイプ $\mathrm{A}^{\prime}$, ・印ではホルマリン除去に長 時易を要することが明らかであります。

以上の成績から, 私たちはH F 型ダイアライザーの洗 浄方法として，灌流液側をシングルパスとし，血液側を 生理食塩水で少なくとも $2,000 \mathrm{ml}$ 以上, 30 分以上にわ たって洗浄する方法が最も優れていることを確認しまし た.この洗浄法を採用してから, 以前, 透析導入時に時々 経験されました静脈穿刺部位の血管痛とか灼熱感などの 症状が見られるなくなりました。

沢西 次に 29 席の木村腎クリニックの松本さんに打 願いします。

松本 ディスポーザブル血液透析ダイアライザーの隇 菌には，エチレンオキシサイドガス，(EOG）が多用され ております．EOG は毒性及び反応性がすこぶる高いた め, 非隇菌物へ存在したものが透析開始時生体内へ流入 し，問題となります，そこで，ダイアライザー中の EOG の残留量及び各種の洗浄方法によるその除去効果につい て検討しました.なお, 今回報告では EOG の測定にはガ スクロマトグラフィを使用し，分析結果をエチレンオキ サイドガス系列化学種, E O 系エチレンクロルヒドリン 系列化学種, $\mathrm{ECH}$ 系列エチレングリコール系列化学種, E G系として解析しました。

ダイアライザーの血液計に蒸留水及び塩酸を注入，5
時間放置し，残留物を溶媒へ抽出させ定量を行った。 メ ラ C - 40, F A-21 を用いた場合の残留物及びその化学種 のガスクロマトグラフは, 図 1 のごとく, ダイアライザー により個有的のパターンが見られます。両者を此較する と, 塩酸で抽出した場合， $\mathrm{E} \mathrm{O}$ 系が $\mathrm{ECH}$ 系及び $\mathrm{E} \mathrm{G}$ 系 のものに相当変化していることがわかります。

図 2 はダイアライザー中にE O 系の洗浄液量による除 去効果を表したものです。上の曲線は血液系のみ生食塩 水を流入したものと, 下の曲線は10 分間透析液に浸し, その後, 血液系に生食水を流入開始したときの除去率を 示しています。透析液に浸したものは，洗浄液 $500 \mathrm{ml}$ 使 用後は洗浄液中での除去率は約 $90 \%, 11$ 使用後には洗 浄液中にはE O系は汪とんど検出されておりません.

$$
\text { メラ } \mathrm{C}-40 \quad \mathrm{FA}-21
$$

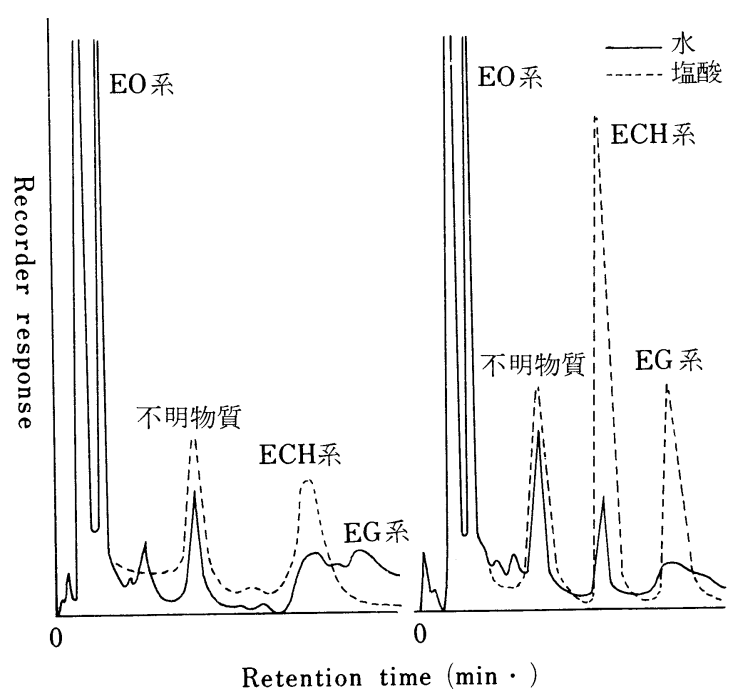

図 I 透析器中の残留物の溶出成分の ガスクロ分析

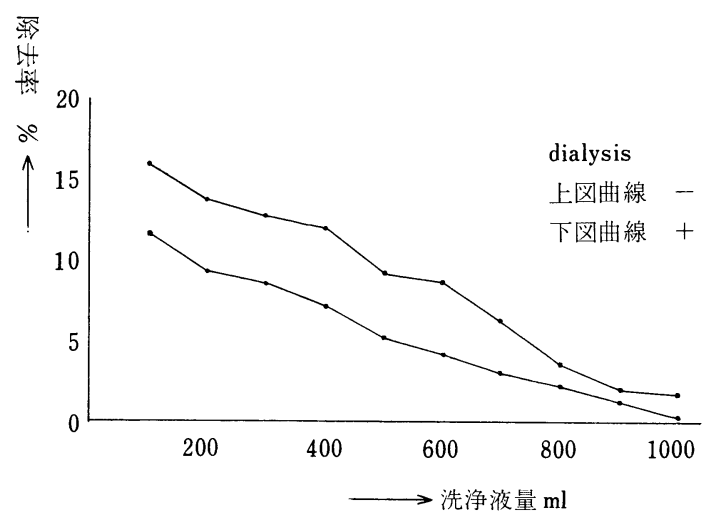

図 2 血液系の洗浄液量と除去率 


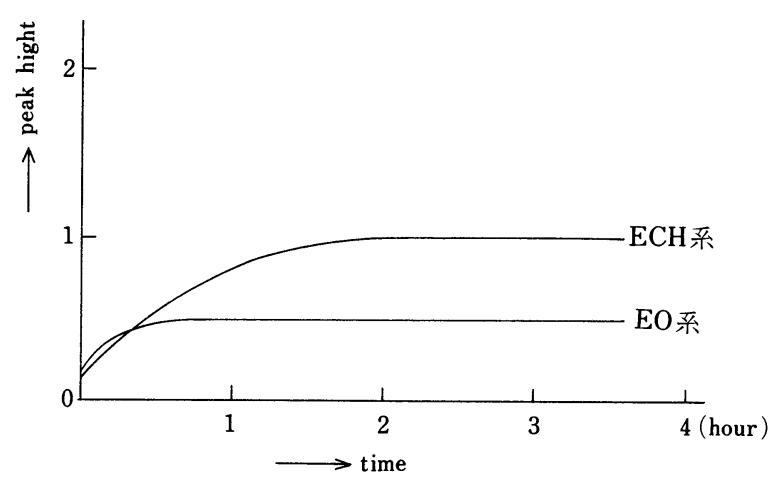

図 3 血液系プライミング液貯溜時間による $\mathrm{ECH} . \mathrm{EO}$ の溶量

図 3 はダイアライザーを生食水 $1 l$ で洗浄後, プライ ミングし，その放置時間による $\mathrm{E} \mathrm{O}$ 系の溶出量を表した ものです. 30 分以内では, 時間の変化と共にかなりの増 加が見られますが, 90 分以上になると変化は見られない ようです. 30 分放置で最初の $3 \sim 4$ 倍のE O量となって おります。これはウルトラフローコイル,スタンダード, メラ C-40にも言えるようです.

浸漬時間によるダイアライザーの残留物変化量をみま すと, E O系では時間による変化が皃とんど見られない のに対し， $\mathrm{ECH}$ 系はわずかながら時間と共に増加の傾 向が見られます。

結果, ディスポーザブルダイアライザーの洗浄液のガ スクロによる測定では, E O 系, ECH 系, E G 系及び不 明物質などの化学種が検出され, 各種ダイアライザーに より特異的なパターメが見られた. 当然のことながら， 洗浄液の多いほど,プライミング液放置時間が長いほど, また透析液に浸漬する時間が長いほど，EOG の除去効 果は高いが, 以上の実験結果から, 生食水 $1 l$ で洗浄後プ ライミングし, 透析液中で 30 分放置した後, ヘパリン加 生食水で再度置換して透析開始する方法が, 生体内への EOG 流入を最小とするのに最適な方法と思われた。

沢西 以上, 大体透析器の洗浄についての演題が固 まって扣りますようですので，ここで一応各演者間で ディスカッションでもあればと思うわけですが，ござい ますでしょらか.

ないよらでしたら，私の方から伺いたいんですけれど も, 25 席の方, これは供給装置も蒸気消毒できるんで しょらか。

雨宮 個人用で，それでできます。

沢西 個人用の場合はできるわけですか.

雨宮 今回使用した装置は個人用ですので, 多人数用 の場合はまだ経験してませんのでわからないですけど.

沢西 どこの病院でも蒸気といらのはあるわけでし
て, それを現在, 装置の消毒といいますと熱湯消毒, こ れも電気を使っての熱湯消毒しているといらことになり ますと，非常に経費が高くつくわけで，できれば，本当 にこらいった供給装置の消毒というのは蒸気でやった方 がいいんじゃないかと思らわけですし，たしか 3 年前で すか, スウェーデンに参りましたときも，向こうで蒸気 で消毒するよらなシステムをとって拈りました。 やはり しかし軟らかい部分というのが問題になりますので，今 後そらいった装置ということになりますと，作る側にも それだけの配慮が必要なわけですが，経費節減という意 味からしますと，そちらの方向に進んでいかなければな らないと思います。

続いて 26, 27, 28 席, この 3 者の演題でございますが, いずれも HFK を使った場合にホルムアルデヒドが残 存する.だからどのぐらい洗わなきゃいかんのかという ことを初期においては非常に頭を痛めたものでございま すけれども，ブラッドライン側をつないで血液ポンプで この血液回路内を回すことによって, ウオッシュアウト の時間といいますが，ホルマリンを追い出すのに時間が かなり短縮されるといら報告をしていただいたわけでご ざいますが, ニュアンスの違いだろうと思うんですが, 30 分でいいと言われた方と, いや, 30 分以上と言われた ような気がしたんですが，もら一度教えていただけない でしょらか. 30 分以内でいいんだという方，それから， いや, 30 分よりもらちょっとした方がいいという意味な んでしょらかね.

松金 僕のところでは 30 分である程度の量は落ちる といらことで, 後, 透析開始までの時間, 患者さんが来 ない場合には当然時間が長いわけですね. そのときに循 環させて敃くといら感じになります.結局 30 分以上とい うことです.

沢西 あとお 2 人の方—.

服部 でされば, 時間があれば 30 分以上した方がいい ということです. 30 分でも，やっぱり残存がありますの で，できたら 30 分以上した方がいいといらことです.

山上 ホルマリン洗浄いたしましたときに，いわゆる 酢酸セルロース，あるいはカプロファンの，ああいうセ ルロース系のメンブランを使ってます場合に，一時的に ホルマリンはゼロになりますが, 1 時間 2 時間放置して 扣さますと，バゥンドしてまいります。我々やりました ときに，30 分で一応ゼロにはなりますが，そのまま放置 して持くとバウンドしていくといら成績を踏まえまし て，文献的な考察を加えまして，それ以上した方がより 効果的であろらというような結論に至ったわけでござい ます。

沢西 ほかにどなたか御意見のある方ございませんで 


\section{しょらか.}

次の 29 席の方の場合, エチレンオキサイドガスの残存 についての洗浄なんですが，何か追加発言の方ございま せんでしょらか。

では，ないようですので，30 席の守山病院の山田さん に㹉いします。

山田 現在当院では,コイル型人工腎臓を主体とし， 約 70 名の慢性腎不全患者の治療を行っている.この度, 透析開始時の時間省力化並びにダイアライザーのリーク テストの精度アップを目的としたオートコイルリーク ディクター（ACLD）を開発製作したので,ここに報告す る.

ACLD は上部に自動回路が組み込まれている制御部, 中央にコイル槽, 加圧ポンプ，下部に透析液供給装置が あります。

ACLD のダイアグラムはコイル槽にテストコイル, 準 備コイルを入れ, 上ぶたを閉じると, 空気排出弁が閉じ, 連動スイッチにより透析液の噴さ上げが開始される。ま た空気加圧ポンプのタイマーもセットされ, 90 秒経過後 にコイル内加圧を始め, 圧力計 $320 \mathrm{mmHg}$ まで昇圧させ る. 30 秒間この状態を維持した後, 空気排出弁が開き, $200 \mathrm{mmHg}$ まで圧下降させる.このとき, クランプ回路, タイマー回路, 時間チャイム回路が作動状態に入り, 空 気加圧ポンプが再び働く．圧力計の指示針が下限設定針 $270 \mathrm{mmHg}$ を超えると, 判定直視の赤ランプから青ラン プに切り換わり，上限設定針 $300 \mathrm{mmHg}$ に達するとクラ ンプされる.そしてタイマー回路が作動する. 90 秒後に チャイムが鳴り, 判定直視ランプが圧テストコイルの合 否を知らせる. 青ランプが合格, 赤ランプが不合格とい ら表示になります。上ぶたを開けると空気排出弁からコ イル内の空気が静かに排出され，すべての回路は開始の 状態に復帰す

一般にコイルの，クテストを行らことは使用の可否 を判定するわけですが，王テスト中，透析中のどちらに もリークのないことが最も望ましいのですから，私たち はこの望ましい条件として, 90 秒, $30 \mathrm{mmHg}$ 圧下降を経 験的に得ましたので，本装置を用いて約 1 年間テストを しました。

この条件に打ける $\mathrm{EX}-01, \mathrm{EX}-03$ の成績を表 1.2 で表しました. キャニスター内で行ら従来方法と ACLD, エア注入王テスト方法の比較をしてみますと, 表 1 のように, EX-01 では圧テストリーク, 透析中リーク 共に, ACLD, ェア注入圧テスト方法が極めてよいことに なります。表 2 のX一03 では, 圧テストリーク，透析 中リーク共に従来方法が良いといら結果になりました.

この 2 つの結果を分析してみますと, $\mathrm{EX}-01$ では, 透

\begin{tabular}{|c|c|c|}
\hline \multicolumn{3}{|c|}{$\mathrm{E} X-01$} \\
\hline \multirow{2}{*}{ 条 } & $\begin{array}{l}\text { 洗浄後, キャ二 } \\
\text { ス夕内压テスト }\end{array}$ & $\begin{array}{l}\mathrm{A} \cdot \mathrm{C} \cdot \mathrm{L} \cdot \mathrm{D} \text { エア } \\
\text { 注入圧テスト }\end{array}$ \\
\hline & $\begin{array}{l}\text { (従来方法) } \\
90 \text { 秒· } 20 \mathrm{mmHg}\end{array}$ & 90 秒 $\cdot 30 \mathrm{mmHg}$ \\
\hline 調 査 個 数 & 1477 & 5677 \\
\hline 圧テスト不合格数 & 61 & 122 \\
\hline 圧テスト不合格率 & $4.13 \%$ & $2.15 \%$ \\
\hline 透析中リーク数 & 6 & 11 \\
\hline 透析中リーク率 & $0.42 \%$ & $0.20 \%$ \\
\hline
\end{tabular}

I 従来方法と $\mathrm{A} \cdot \mathrm{C} \cdot \mathrm{L} \cdot \mathrm{D}$ エア一注入圧テスト方法の比較

\begin{tabular}{|c|c|c|}
\hline \multicolumn{3}{|c|}{$\mathrm{E} X-03$} \\
\hline \multirow{2}{*}{ 条 } & $\begin{array}{l}\text { 洗浄後, キャ二 } \\
\text { スタ内圧テスト }\end{array}$ & $\begin{array}{l}\mathrm{A} \cdot \mathrm{C} \cdot \mathrm{L} \cdot \mathrm{D} \text { エア - } \\
\text { 注入圧テスト }\end{array}$ \\
\hline & $\begin{array}{l}\text { (従来方法) } \\
90 \text { 秒 } \cdot 20 \mathrm{mmHg}\end{array}$ & 90 秒 $\cdot 30 \mathrm{mmHg}$ \\
\hline 調 查 個 数 & 907 & 3366 \\
\hline 圧テスト不合格数 & 28 & 151 \\
\hline 圧テスト不合格率 & $3.09 \%$ & $4.49 \%$ \\
\hline 透析中リーク数 & 4 & 23 \\
\hline 透析中リーク率 & $0.46 \%$ & $0.72 \%$ \\
\hline
\end{tabular}

衰 2

析中リークのある月の圧テストリーク率は, 透析中リー クのない月の 2 倍にはなっていますが，従来方法よりも 圧テストリークを低く抑えることができ，かつ透析中 リークも低くなっている.これは $\mathrm{EX}-01$ に拈いてはテ スト条件が合致し，また EX一01 峖定した製品であ り，かつ ACLD のリーク発見能力が優れていると考え られます.しかしながら, EX-03 では, 透析中リークの ない月とある月の王テストリーク率はかなり高い值で, ほぼ同率を示しています。また透析中リークのある月の 透析中リーク率は極めて高い値を示していることもわか ります。これは 90 秒 $30 \mathrm{mmHg}$ 圧下降の条件下では, 透 析中リーク，圧テストリークが共に高いのですから, 少 なくとも透析中リークを減少させるためには，条件を厳 しくさせる必要があります．しかしその結果として圧テ ストリーク率が高くなるのは避汁られないと考えられま す.

な拉，調査期間中， $\mathrm{EX}-03$ が $\mathrm{EX}-01$ よりも製品の 質低下及びそのバラつきが多かったように思われるの で，今後も検討する考えであります。

ACLD を使用するようになっでから, 透析開始時に は, 洗浄, プライミングのみを行えばよく，従来より 30 分以上も早く透析を開始でさ，1 日の透析治療業務に抹 
いても，時間的余裕のあるときにリークテストが行光， 1 日の仕事量のバランスがとれるようになりました。

沢西 31 席の県立厚木腎センタ一の木村さんに打願 いします。

木村 セロファン膜やカプロファンを材料としたコイ ル型ダイヤライザーの脆弱性には宿命的なものがあり, 取扱いによってリークやバーストの発生率に著しい差が 生じます．今回我々は，コイルに対して重大な負荷であ る圧テストがコイルのリーク率に与える影響を観察し, 圧テストの意義を検討しました. 対象は県立厚木病院と 厚木クリニックで使用したコイル延べ 2,000 個で, 圧テ ストを各社の規定ど和り行ったものと行わなかったもの とのリークの発生率を比較検討しました. 限外濾過圧は 100〜150mmHg です.

圧テストとバースト率

\begin{tabular}{|c|c|c|c|c|c|c|}
\hline \multirow[b]{2}{*}{ UF $_{2}$ standard } & \multicolumn{2}{|c|}{ 圧テスト不合格 } & \multicolumn{2}{|c|}{$\begin{array}{c}\text { 圧テスト合格 } \\
\text { 透析中リーク・バースト }\end{array}$} & \multicolumn{2}{|c|}{$\begin{array}{c}\text { 圧テスト不施行 } \\
\text { 透析中リーク・バースト }\end{array}$} \\
\hline & $2 / 567$ & $0.3 \%$ & $10 / 565$ & $1 \%$ & $2 / 227$ & $0.8 \%$ \\
\hline $\mathrm{UF}_{2} 1.5 \mathrm{M}^{2}$ & $2 / 52$ & $3 \%$ & $4 / 50$ & $8 \%$ & $3 / 99$ & $3 \%$ \\
\hline Ex 23 & $1 / 121$ & $0.8 \%$ & $3 / 118$ & $2.5 \%$ & $1 / 203$ & $0.4 \%$ \\
\hline Dc 7 & $0 / 96$ & $0 \%$ & $0 / 96$ & $0 \%$ & $0 / 151$ & $0 \%$ \\
\hline $\mathrm{Kc}-08$ & $0 / 110$ & $0 \%$ & $0 / 110$ & $0 \%$ & $0 / 75$ & $0 \%$ \\
\hline$K c-10$ & $0 / 98$ & $0 \%$ & $0 / 98$ & $0 \%$ & $2 / 201$ & $0.9 \%$ \\
\hline
\end{tabular}

\section{衰 I}

表 1 に示すと特り $\mathrm{DC}-7, \mathrm{KC}$ コイルにはリークがほ とんどありません．これに対してウルトラフローII，1. $5 \mathrm{M}^{2}$ コイルでは圧テスト不合格が $3 \%$ あり, 透析中の リークも $8 \%$ を示しました. 一方, EX-23, ウルトラフ ローIIスタンダードコイルでは，圧テスト不合格がそれ ぞれ $0.8 \% ， 0.3 \%$ と低く，また透析中のリーク率も，2. $5 \% ， 1 \%$ と低值を示しています. 圧テストに不合格のコ イル数と, 王テストに合格後透析中にリークを起こした ものとの合計は, $\mathrm{EX}-23$ で $3.3 \%$, ウルトラフローII ス タンダード $1.3 \%$, ウルトラフローII $1.5 \mathrm{M}^{2}$ で $11 \%$ であ るのに対し，圧テストを行わずに透析を行い，透析中に リークを呈したものはそれぞれ $0.4 \% ， 0.8 \% ， 3 \%$ ， 前者の $1 / 3$ から 1/4 となっています。またこの值は，圧 テストで不合格になる各コイルの数にほぼ当てはまりま す.

以上より，圧テストで合格しながら透析中にリークを 起こすコイルがあり，そのリーク率は圧テストを行わな いコイルより高く, しかもリークの発生は透析開始直後 に集中しています。この事実は，圧テストがコイルに損 傷を与えていることを示唆して扣り，通常，限外濾過圧 を 100 150mmHg 前後に設定する場合，圧テストは行 ら必要がないと考えます。
圧テストを行わずに透析を開始した場合，リークの早 期発見が肝要となります.我々は, 日機装 CD-11 型装置 に漏血チャンバーを取り付け，現在まで，ごくわずかの リークでも，すべてこのチャンバーで発見しています.

透析終了時に $5 \%$ グルコースか生食水 $500 \mathrm{ml}$ のびん に，2本の 18 ゲージ針を穿刺し，血液回路の動脈側端を ガラス管以外の 18 ゲージ針につなぎ,この位置で血液ポ ンプを回転させると, 室内の空気が水中を通ってコイル 内に流れ込みます。

このように水をフィルターとして使用したときと，室 内空気をそのままエアリンスに使用したときとにつき， 各々の空気中の塵埃数をクライメットパーティクルカウ ンターCL-250を使用して測定しました。

室内空気をそのままコイルに送り込むと，室内塵埃の 約 $1 / 2$ がコイル内血液に混じり, 残り $1 / 2$ は回路内やコ イル膜に付着します。一方，水をフィルターとして使用 した場合には, $0.5 \mu$ から $10 \mu$ までのすべての塵埃が水に 吸着され，血液を活染することなくリンスできることを 示しました（表 2 ）.

\section{リンスエア中の塵埃数}

\begin{tabular}{|c|c|c|c|}
\hline \multicolumn{2}{|c|}{$\begin{array}{c}\text { 透析室内塵埃数 } \\
\mathrm{ft}^{3}\end{array}$} & $\begin{array}{l}\text { 室内空気を } \\
\text { 使用 }\end{array}$ & $\begin{array}{l}\text { 室内空気を } \\
\text { 水中を通し } \\
\text { て使用 }\end{array}$ \\
\hline $0.5 \mu$ & 449,600 & 181,500 & 0 \\
\hline $1 \mu$ & 70,900 & 32,100 & 0 \\
\hline $2 \mu$ & 13,900 & 6,200 & 0 \\
\hline $5 \mu$ & 1,700 & 100 & 0 \\
\hline $10 \mu$ & $100 \downarrow$ & $100 \downarrow$ & 0 \\
\hline
\end{tabular}

衰 2

沢西 次に 32 席の三愛病院の中村さんに打願いしま 于.

中村 血液透析を開始して 1 年半を経た現在ですが, 私たらの施設では，仕事の能率と清潔，安全を保つため に，工夫を小さなことであっても，少しでも改善できれ ばと思い心がけてまいりました。

貧血は透析患者にとって大きな問題で，血液の損失を 少しでも防ぐことが大切であり，透析中のコイルのリー クを防止し，血液回路内残血を少なくするために，私た ちの実施している方法を発表させていただきます。

コイルを乾燥状態でいきなり洗浄することは，クプロ ファン膜の間を無理に押し開くため,リークの誘因とな り，またクプロファン膜の性質からも，王テストは十分 
湿潤した状態で行らべきと考えられます。文献を参考に, コイルを一晚水槽に浸しましたが，実用的でありません でした.

そこで，私たちは早番を設け，まず水の入っている透 析槽内にコイルを浸し, 15 分後に循環させ, 次に $5 \%$ ブ ドウ糖液 $500 \mathrm{ml}$ で回路内とコイルの洗浄を行い,十分に クプロファン膜を湿潤させた後に圧テストを行っていま す.

私たちの施設の透析中のリークは, UF-II 3,315 個中 22 個, DC-7, 1, 328 個中 10 個で, 透析延べ 4,643 回中 32 回， $0.69 \%$ のーク率であり，最近他施設のリーク率の 発表がありませんが，昭和 47 年の他施設のリーク率は $6.45 \%, 1.33 \%, 0.73 \%$ の報告に比較し, 良いと思われ， 早番の仕事は重要であると考えております。

次に回収は，動脈穿刺針を抜き，補液ラインのところ まで血液を空気で送り, 次に補液ラインを開放し, 生理 食塩液で回収しておりましたが, 動脈側先端から補液ラ インまでの回路内に残血が認められますので，その量を 測定してみました。

回収終了後に補液ラインから生理食塩液 $100 \mathrm{ml}$ を動 脈側先端の方へ逆流させて, 残血を洗浄採取し, 赤血球 算定法を応用した赤血球数を数えます。次の計算式で患 者血液量に換算しました. 残血量 $=$ 洗浄液中赤血球数 $\div$ 患者赤血球数 $\times 100.40$ 例について測定したところ, 残血 量平均 $1.4 \mathrm{ml}$ でした，後述いたしますが，改善した回収 方法で回収し, 調べた平均, 回路, コイル内残血量 $1.2 \mathrm{ml}$ で，私たちが現在行っている方法が有効であることがわ かりました。

改善方法として, 最初に回収の途中で補液ラインから 生理食塩液を動脈側先端に逆流させて残血を洗浄回収し てみましたが，効率が悪く，逆流時に血液滴下などの問 題がありました，次に補液セットのゴム管部分やクー パーで切断した補液ラインに動脈側先端を接続してみま したが，十分な清潔を保てなかったり，手技も繁雑にな りました。

現在は補液ラインの血液回路から約 $15 \mathrm{~cm}$ のところ に, 回路側が凸, 回収液側が凹のコネクターが入った血 液回路を特注作製してもらいました。プライミングなど に通常の補液ラインとして使用し, 回収時にはコネク ター部分で補液ラインをはずして, 患者から抜去した動 脈側先端に接続し，生理食塩液で回収して扮ります。こ の方法は操作が簡単で清潔を保つことができ，動脈側回 路側残血も完全になくすることができました.
沢西 以上 3 題, リークといらことに関して，例えば 30 席の方は, むしろディテクターを作ってチェックする といら積極的な姿勢を持っておられる。しかしながら， 実際的に圧テストをして合格していながら，実際はバー ストを起こしたりリークを起こす率といらのが結構高い んだから，圧テストは余り意味がないんじゃないかとい らのが 31 席の方の扔考光。また 32 席の方の場合には, 非常にリーク率が低いので私驚いていたんですけれぞ も，十分初めに水にしたせばいいんだというようなこと ではなかったかと思いますが，各演者間でこのリーク率 の差といらことについてのディスカッションはないで しょらか。

ないようでございます。

この受け持ちましたセクション 2 でございますけれど も, 全体的にこうして透析そのものが非常に広まってき, また長期化してまいりますと，皆さん方は非常に積極的 に残血を抑劣，またりークを抑えることによって，患者 の貧血対策, 真剣に取り組んで扔られるのに敬意を表し ますと共に，今後の更に一層の努力を打願いするわけで すが，ただこういったものを今論じていただきました場 合にでも，まだェアで押し戻すという問題.これはやは りコッヘルがはずれましたりしますと非常に危険な状態 が起こり得るわけでございますし，何かこらいったこと にでも更に安全な対策といらことを立てていただきたい ように思います。

また残血量といらのは案外へパリン量と関係があるわ けでございまして，へパリンを多く使えば残血量も当然 少なくなってくるだろらと思うわけですが，そらかと いって，へパリンを余り多く使いたくない。個々の患者 に合わせたへパリンの使用ということを考光ながら残血 を少なくさせていただきたいと思います。

な报，ホルムアルデヒドの HFK 内の残存という問題 に関しましては, ブラッドライン，これをよくサーキュ レーションさせることによってかなりの改善を見るよう でございますが，これも長期にわたりますと，本当に微 量のものが入っても問題にならないのかどらか。これは 2 年, 3 年, 5 年, 10 年々, 本当に長期間見ていかない ことには，安全であるといら数值といらのは出ないわけ でございますので，今後一層の努力をお願いしたいと思 います。

時間が参りましたので，この辺で終了させていたださ ます。 